\title{
Sociedade civil, Estado e autonomia: argumentos, contra-argumentos e avanços no debate
}

\author{
Adrian Gurza Lavalle \\ Departamento de Ciência Política \\ Universidade de São Paulo \\ Centro de Estudos da Metrópole e Núcleo Democracia e Ação Coletiva \\ Centro Brasileiro de Análise e Planejamento \\ José Szwako \\ Núcleo Democracia e Ação Coletiva \\ Centro Brasileiro de Análise e Planejamento \\ Programa de Pós-Graduação em Ciência Política \\ Universidade Federal do Paraná
}

\begin{abstract}
Resumo: 0 cenário brasileiro das relações entre Estado e sociedade civil tem se reconfigurado ao longo das últimas três décadas, suscitando esforços da literatura especializada para diagnosticar tais mudanças mediante deslocamentos analíticos e revisões de pressupostos. Em diálogo com um diagnóstico recente de conjunto que recoloca algumas teses importantes na literatura e segundo o qual essa reconfiguração é uma passagem de um período histórico de autonomia plena dos atores sociais para um momento de interdependência com o Estado, o artigo desenvolve quatro contra-argumentos amparados em deslocamentos teórico-analíticos e metodológicos que, junto à extensa pesquisa empírica, marcam avanços no debate do país sobre as relações socioestatais. Os contra-argumentos partem do pressuposto da mútua constituição, ou codeterminação, entre Estado e sociedade civil e revisam criticamente os argumentos sobre a emergência tardia da sociedade civil no Brasil, seu nascimento sob o signo de uma não relação com o Estado e os partidos políticos, bem como sobre o advento da interdependência com o Estado no período pós-constituinte. No seu todo, o conjunto dos contra-argumentos mostra os ganhos analíticos de uma perspectiva centrada nas interações socioestatais e de uma compreensão relacional de autonomia tanto no plano da prática dos atores quanto no plano da teoria.
\end{abstract}

Palavras-chave: interações socioestatais; Estado; sociedade civil; movimentos sociais; autonomia

Abstract: The relationship between civil society and state has dramatically changed in Brazil along the last three decades. Civil society, social movements and participatory democracy literature have engaged in revising its underpinning assumptions in order to build a comprehensive diagnosis of such changes. This article presents a critical appraisal of the trends and theoretical innovations on the state-civil society contemporary Brazilian debate. It specifically examines a recent comprehensive diagnosis that updates some important conventional ideas about the Brazilian civil society. Such diagnosis describes and grasps the meaning of such changes as a historical shift between two moments: from an autonomous to an interdependent civil society vis-à. vis the state. We challenge such ideas from the standpoint of a relational and historical approach of state-civil society relation as mutually constitutive and drawing on an extensive literature review of both recent empirical studies on Brazilian civil society and sound grounded theory building diagnosis. We show that the ideas of the late birth of Brazilian civil society, the non relation between civil society, and political parties and the state during dictatorship, as well as the interdependence between them as a recent phenomena are conceptually and empirically flawed. Overall, we show the analytical benefits of an interactive and relational approach of state civil society interactions and autonomy.

Keywords: social and state interactions; State; civil society; social movements; autonomy

OPINIÃO PÚBLICA, Campinas, vol. $21, n^{\circ} 1$, abril, 2015, p. 157-187 
Introdução $^{1}$

O cenário brasileiro das relações entre Estado e sociedade civil tem se reconfigurado ao longo das últimas três décadas, suscitando esforços da literatura para diagnosticar tais mudanças. Em paralelo e junto à redemocratização política, uma quantidade cada vez maior de atores societais passou a travar diferentes modalidades de interação com autoridades legislativas, executivas e judiciárias, de modo a ampliar as chances de verem institucionalmente incorporadas suas demandas. São inúmeros os exemplos que, nos três níveis da administração pública, ilustram a institucionalização em maior ou menor medida dessas demandas, da proliferação de instâncias participativas à configuração de políticas setoriais em áreas como saúde (SUS) ou habitação (Estatuto da Cidade, Sistema Nacional de Habitação de Interesse Social), da formação de subcampos específicos de políticas (campo da saúde da população negra ou dos direitos da criança e do adolescente) às inúmeras disposições que tornam obrigatória a validação social de investimentos de grande porte mediante audiências e outros dispositivos de incorporação da perspectiva dos afetados. Por sua vez, a literatura ocupada no percurso dos anos 1980 , 1990 e 2000 com movimentos sociais, sociedade civil e espaços participativos está às voltas com o equacionamento de diagnósticos de conjunto sobre tais mudanças e suas implicações, e também com revisões de seus pressupostos teóricos de modo a incorporar sistematicamente o Estado e os partidos a seus quadros analíticos.

Deslocamentos e revisões de pressupostos são claramente perceptíveis na literatura especializada. Tais revisões fazem avançar o debate, revisando ou abrindo mão de conceitos e de posturas interpretativas, cujos excessos normativos ou de outra ordem mais limitam do que expandem o alcance das análises. Exemplo desse esforço pode ser visto na tentativa de "estudar o ativismo através da fronteira entre Estado e sociedade" (ABERS; VON BULOW, 2011). Contra interpretações que enfatizaram a oposição entre atores estatais e não estatais, as autoras argumentam que a "unidade de análise não deve necessariamente excluir atores que estão posicionados dentro da arena estatal" (ABERS; VON BULOW, 2011, p. 54). A própria ideia do Estado como um aparato burocrático munido de autoridade, conhecimento especializado e capacidade de ação, quando interpelado pelas instituições participativas por ele institucionalizadas, tem sido funda e criteriosamente revisada (ABERS; KECK, 2013). Nesse mesmo sentido, outras análises sugerem uma expansão analítica que engloba e ultrapassa a "arena estatal", enfocando as formas institucionalizadas de participação não a partir da sociedade civil, mas do sistema político e em relação direta com atores partidários - ambos largamente eclipsados no debate (RomÃo, 2010). Outro flanco dessa renovação nos estudos sobre a sociedade civil tem explorado, em revisão de certos pressupostos deliberativos e/ou participacionistas, as funções de representação desempenhadas

\footnotetext{
${ }^{1}$ Gurza Lavalle agradece o apoio institucional, durante a redação deste artigo, do Institute for European Studies e do Centre for the Study of Democratic Institutions, ambos da Universidade de British Columbia, bem como o auxílio 2012/18439.6 da Fundação de Amparo à Pesquisa do Estado de São Paulo (Fapesp). Também agradece o financiamento do Centro de Estudos da Metrópole (Cebrap, USP), processo n²013/07616-7, Fundação de Amparo à Pesquisa do Estado de São Paulo (Fapesp). As opiniões, hipóteses e conclusões ou recomendações expressas são de responsabilidade dos autores e não necessariamente refletem a visão da Fapesp.
} 
GURZA LAVALLE, A.; SZWAKO, J. Sociedade civil, Estado e autonomia: argumentos...

por atores sociais nas hoje chamadas instituições participativas (LÜCHMANN, 2011; GURZA LAVALLE; Houtzager; CAstello, 2006a; 2006b). Nessa última seara, não têm sido poucos os esforços, acadêmicos e oficiais, empreendidos para desenvolver instrumentos capazes de mensurar de modo fidedigno os efeitos das instituições participativas, seja nas políticas, seja na institucionalidade estatal mais amplamente (e.g., Pires, 2011). As referências poderiam se multiplicar, mas não é o objetivo aqui abarcar os investimentos feitos na renovação das análises sobre movimentos, sociedade civil e participação; fazer jus à diversidade dessas análises e seu valor de inovação analítica demandaria uma análise exclusiva.

O que importa por ora, com esses exemplos, é atentar para os esforços de revisão conceitual a partir de diferentes enfoques e variadas instâncias empíricas - não necessariamente restritos à participação institucionalizada -, os quais têm enriquecido o debate e o feito avançar. Metáforas como "fronteira" e "franja", termos como "ativismo do Estado" ou "mobilização do Estado", ou conceitos como "projeto", "domínio de agência", "autoridade prática", ou outros incorporados à argumentação mais adiante, não deixam dúvida: a entrada do sistema político e as interações entre atores estatais e não estatais têm pesado na renovação das equações analíticas ${ }^{2}$. Atores, interações, instituições e efeitos comparecem como componentes dessas equações visando a formular diagnósticos capazes de apreender o cenário de pluralização institucional e complexificação da democracia no país.

Em artigo recente e pioneiro, Leonardo Avritzer (2012) elaborou diagnóstico de conjunto sobre o período, reatualizando em nova interpretação algumas das teses sobre a autonomia dos movimentos sociais e da sociedade civil que caracterizaram a literatura nos últimos 20 anos ${ }^{3}$. 0 diagnóstico é desconcertante e singelo. Nele, as transformações ocorridas nas relações entre sociedade civil e Estado nos últimos 40 anos da história do país são equacionadas como uma evolução em três momentos. No Brasil, como, de resto, na América Latina, dadas as peculiaridades da modernização na região, a sociedade civil teria emergido de forma assaz tardia. No país, seria possível datar essa emergência nos anos 1970, em um primeiro momento de "autonomia plena"4 (p. 392) animado por um "movimento pela autonomia social" (p. 386) em relação ao Estado. A Constituinte teria encerrado esse período, ensejando a "criação da interdependência política" (p. 390) entre atores sociais e Estado. A inauguração da interdependência teria cedido passo, com o aprofundamento da democratização do país, a um momento em que a sociedade civil seria "mais ou menos autônoma vis-à-vis o Estado". Assim, o momento atual poderia ser bem compreendido como marcado por uma "lógica mista de autonomia e dependência" que varia conforme a dois grupos maciços de associações que constituiriam a composição da sociedade civil brasileira: associações religiosas e aquelas vinculadas ao Estado para a implementação de políticas públicas. Subjaz ao diagnóstico histórico, cumpre destacar, o empenho analítico de reabilitar o conceito

\footnotetext{
2 Para as metáforas "fronteira" e "franja", ver Abers e Von Bulow (2011) e Romão (2010); para o termo "mobilização do Estado", ver Abers e Keck (2009); para os conceitos “projeto", "domínio de agência”, "autoridade prática”, ver respectivamente Dagnino, Olvera e Panfichi (2006), Gurza Lavalle, Houtzager e Castello (2012), Abers e Keck (2013). O termo "ativismo de Estado" aparece em Hochstetler e Keck (2007), mas por outras vias seu uso vem ganhando difusão, como mostrado por ementas de mesas e grupos de trabalho entre 2011 e 2013 na Anpocs.

3 Quando da revisão da versão original deste artigo para incorporar as observações pertinentes dos pareceristas, entramos em contato com interessante exame crítico, suscitado pelo mesmo artigo de L. Avritzer, acerca do modelo de sociedade civil por ele abraçado (ver Burgos, 2014).

${ }^{4} \mathrm{~A}$ partir daqui aspas duplas indicarão citações e termos com carga analítica tal como utilizados nos textos de referência. Por sua vez, aspas simples indicarão o uso de termos cujo conteúdo é infirmado ou suspenso, bem como vocábulos nativos.
} 
de autonomia da sociedade civil - sem alterações ou tal como utilizado pelo próprio autor e por parte importante da literatura ao longo dos anos 1980, 1990 e começo dos 2000 -, revisitando en passant as críticas a ele formuladas.

Nas páginas deste texto nos beneficiamos do esforço de síntese e atualização de tal artigo e desenvolvemos uma crítica iluminando teses e limitações a partir dos avanços observados no debate. A reflexão de L. Avritzer é, sem dúvida, contribuição que estimula o debate a respeito de um conjunto de transformações perscrutadas em registros diversos na literatura e para as quais ainda carecemos de visões de conjunto sedimentadas conceitual e empiricamente. Nesse aspecto, trata-se de um esforço bem-sucedido, em linha de continuidade com o papel de outros trabalhos do autor na ampliação das fronteiras do campo de estudos sobre a sociedade civil e a participação (AVRITZER, 1997; 2009; AVRITZER; NAVARRO, 2003). Porém, o diagnóstico em questão - e as teses da literatura que reatualiza - nos parece um retrocesso em relação ao avanço da literatura do campo nos últimos 20 anos, à progressiva sofisticação metodológica que acompanhou esse desenvolvimento e à riqueza da pesquisa empírica produzida pela comunidade acadêmica em campos afins. A crítica opera em vários planos aproveitando a sequência e a lógica argumentativa que sustenta o diagnóstico de Avritzer. Visamos a mostrar, primeiro, que uma visão emergentista da sociedade civil que irrompe no último quartel do século XX e evolui em etapas da autonomia plena à semidependência é equivocada empírica e conceitualmente; segundo, que a plausibilidade de diagnósticos autonomistas está assentada em operações epistêmica e metodologicamente insustentáveis, as quais borram as fronteiras entre os usos teóricos e práticos das categorias, bem como entre evidências e inferências.

Com intuito de organizar a exposição da crítica e, sobretudo, de favorecer o aprofundamento do debate em torno de teses assentes na literatura, as páginas que seguem exploram contra-argumentos. A cada contra-argumento corresponde um argumento. Conjuntos articulados de ideias explícitas, evidências mobilizadas e pressupostos implícitos configuram os argumentos, e eles são peças relevantes para os propósitos conceituais e de diagnóstico de conjunto do artigo de Avritzer, bem como reformulam e atualizam, à luz da história recente do país, teses importantes nas literaturas nacionais de movimentos sociais e sociedade civil. O texto está ordenado em quatro argumentos e contra-argumentos. Quanto aos primeiros, sua enunciação em uma única frase desempenha uma finalidade heurística, a saber, trazer à tona imediatamente os aspectos que, a nosso ver, merecem exame cuidadoso pela sua centralidade no diagnóstico oferecido pelo autor e sua relevância na literatura. A exposição e a reconstrução dos argumentos, por sua vez, procedem de modo inverso, isto é, lançam mão do texto original, para mostrar literalmente os termos em que operam. Assim, a enunciação sintética pode ser ponderada pelo leitor mediante a reconstrução dos argumentos. Quanto aos contra-argumentos, seu desenvolvimento não é paralelo ou estanque, eles mantêm antes interlocução progressiva e transversal entre as seções, cuja síntese está na conclusão. 
GURZA LAVALLE, A.; SZWAKO, J. Sociedade civil, Estado e autonomia: argumentos...

Modernidade e emergência da sociedade civil tardia no Brasil

O conceito de sociedade civil não seria aplicável ao contexto brasileiro, "pelo menos, até o início do século XX [devido] a uma situação de pouca diferenciação entre privado e público" (AVRITZER, 2012, p. 384). No século XIX, o conceito seria apropriado somente para realidades de algumas latitudes não meridionais, nos "países do Atlântico Norte", onde dois processos teriam configurado a "modernidade ocidental", quais sejam, "a diferenciação entre as esferas econômica e familiar com a abolição da escravidão, bem como a diferenciação entre Estado e sociedade causada pela especialização sistêmica do Estado" (AVRITZER, 2012, p. 384). Para o caso brasileiro, falar propriamente em sociedade civil só faria sentido no contexto do regime militar dos anos 1960 e 1970, tomando-a como uma noção adequada para "diferenciar os novos atores sociais emergentes tanto do mercado como do Estado autoritário" (p. 385). Vários fatores e atores estiveram implicados na "emergência" setentista da sociedade civil brasileira: i) a intensa urbanização (p. 386); ii) o viés tecnocrático das políticas daquele regime (p. 386); iii) a reação das classes médias e populares àquele viés (p. 386.387); e iv) o incremento das associações "entre 1974 e 1985" (p. 387). Em conjunto e sob o signo distintivo da autonomia, esses fatores desaguaram numa realidade que, apenas desde então, passaria a merecer o rótulo sociedade civil, porquanto dotada de 'densidade associativa', 'propensão crescente para a associação', reivindicações de benefícios materiais para a 'comunidade', bem como 'reivindicações pós-materiais' ( $p$. 388). Caracterizações semelhantes sobre a índole inédita da irrupção da sociedade civil já tinham sido elaboradas alhures, no final dos anos 1990, como o argumento do "novo associativismo"5; mas compreensões que enfatizavam a emergência da sociedade civil e de seus atores, com predicados correlatos a sua atuação 'autônoma', plural e densa, ante o mercado e o Estado, foram compartilhadas por vários autores no debate (cf. Scherer-Warren, 1999; Costa, 1994; 1997) e criticadas por tantos outros (cf. Cardoso, 1983; Boschi, 1987; Diniz e Boschi, 1989).

Esse primeiro argumento tanto sofre de déficits historiográficos e analíticos como se torna possível graças a eles. O diagnóstico de a sociedade civil ter deitado raízes só no último quartel do século passado depende de uma dupla exigência analítica, qual seja, a irrupção da diferenciação entre sociedade e Estado nesse momento e a suposta falta de diferenciação entre ambos no Brasil do século XIX. Assumida como certa, ela autoriza uma postura, por assim dizer, emergentista: "descrevo o surgimento da sociedade civil no Brasil durante os anos setenta" (AVRITZER, 2012, p. 386). Mais que um objetivo da análise, trata-se de um parti pris: a sociedade civil, junto da modernidade a ela associada, teria nascido entre nós naqueles anos - resta apenas descrevê-la. Como notou P. Bourdieu (1998), toda descrição tende a operar de modo prescritivo, seja porque seu realismo contribui para a autoconstatação, e não, ao contrário, para uma verificação hipotética - nesse caso, de uma gênese civil e setentista - a ser matizada ou mesmo refutada; seja porque as propriedades invocadas pelo discurso teórico - nesse caso, densidade e pluralismo - coadunam com a imagem e a autoimagem (autonomistas)

\footnotetext{
${ }^{5}$ Veja-se: “[o] novo associativismo constitui um fenômeno formado por três componentes [...]: [densidade, isto é,] um aumento expressivo no número e no ritmo de constituição de associações civis [...]. Uma ruptura com um padrão homogeneizante de ação coletiva [reivindicações plurais, ou seja, materiais e pós-materiais]. [...] Parece bastante claro que a maior parte dos atores já não busca a sua incorporação ao Estado [aqui um duplo signo, autonomista e autolimitante]" (AvRITZER, 1997, p. 97).
} 
do objeto descrito. Embora se valha do efeito de teoria, fazendo com que a descrição pressuposta corresponda a divisões reais, esse argumento é histórica e analiticamente equivocado, e não leva em conta os avanços da produção de conhecimento conquistados no debate historiográfico recente sobre a vida associativa nos e através dos processos sociopolíticos do Brasil do século XIX. Vejamos alguns desses avanços e processos à luz das propriedades reputadas como distintivas dos 'atores emergentes' dos anos 1970.

A existência de associações de auxílio ou socorro mútuo, bem como a quantidade expressiva dessas mutuais ou 'sociedades' na passagem do XIX para o XX, não é algo novo no debate historiográfico ${ }^{6}$. Novos, porém, são os dados e desdobramentos recentes do debate sobre mutualismo: quase $80 \%$ das associações mutuais fundadas no período entre 1815 e 1904 na capital do Império e da República tiveram sua criação a partir de 1875 (VISCARDI, 2009). Em sintonia com esse dado e a partir de outras fontes, "encontramos 310 registros de associações criadas na cidade do Rio de Janeiro entre 1860 e 1889" (JESUS, 2007, p. 147). Embora variem muito, sendo 'sociedades' religiosas, científicas, literárias, dentre outras, o tipo de consociação quantitativamente mais significativo nesses números são as mutuais beneficentes. Estas, por sua vez, perfazem um variado leque: mutuais gerais, de ofício, de classe, de libertos, de imigrantes/ou comemorativas, filantrópicas, regionais e, por fim, de empresários e comerciantes.

Esses dados dizem respeito a um tecido associativo não desprezível, já no fim do XIX, interposto entre o poder imperial e o domínio da Casa Grande. Essas associações, contudo, podem não satisfazer uma concepção mais exigente de sociedade civil, pois

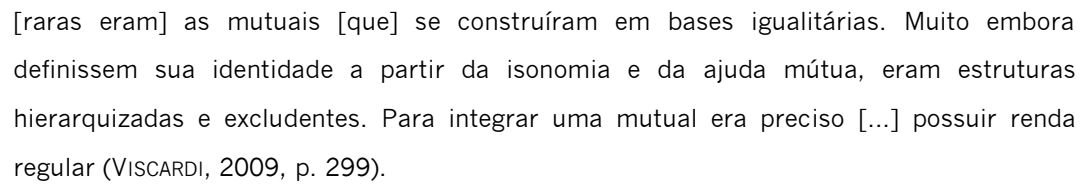

Não foram, contudo, os limites históricos excludentes, notadamente de 'raça' e gênero, mas igualmente de classe, impostos pela dinâmica associativa, que impediram que se falasse de vida pública e civil em latitudes do hemisfério norte e que se teorizasse a seu respeito (HABERMAS, 1994). Talvez seja outra a limitação que nos impeça de falar de sociedade civil no fim do XIX: as mutuais teriam restrito alcance geográfico, elas mal passariam da capital. Ledo engano. Em 1917, o Rio de Janeiro concentrava pouco menos de $25 \%$ de todas as entidades desigualmente distribuídas pelo país e censadas pelo governo de então (SILVA JR., 2004, p. 51-ss.). Diante dessa vida associativa, não surpreende que Silva Jr. afirme que "o otimismo [de Avritzer] com a sociedade civil do Brasil contemporâneo fundamenta-se em apreciações ainda deficientes sobre o que ela já foi" (2004, p. 67).

O diagnóstico do "novo associativismo" não desconhece empiricamente o fenômeno das mutuais:

\footnotetext{
${ }^{6}$ No Rio de Janeiro da Primeira República, as associações de auxílio mútuo chegaram a mais de 282 mil associados, ou seja, aproximadamente 50\% da população de mais de 21 anos (CARVALHO, 1996).
} 
[elas] representaram um padrão de ação coletiva no qual o desenvolvimento da solidariedade social implicava imediatamente o desenvolvimento de organizações com tendência à homogeneização dos interesses representados [...] diluindo [a solidariedade] em organizações representativas de um interesse genérico de classe e uma identidade genérica de povo (AVRITZER, 1997, p. 163).

Porém, subsume analiticamente as mutuais à dimensão de classe, a uma imaginada "homogeneização dos interesses" corporativa e não "verdadeiramente plural" (AVRITZER, 1997, p. 160). E mais: a despeito daquele variado leque das mutuais e de seu alcance geográfico, tomam-se as mutuais como sinônimo da falta de pluralidade - uma das bases da suposta e latino-americana "debilidade original" (1997, p. 153-ss.).

Um dos mais importantes avanços conquistados pelo debate sobre mutualismo foi justamente desligá-lo do diapasão dos estudos sobre classe trabalhadora e história do trabalho. Contra anacronismos e a favor da variedade própria àquelas formas de consociação, os estudos de ponta sobre as mutuais têm insistido que elas não devem ser tratadas como a pré-história dos sindicatos (SILVA JR., 2004, p. 22-ss.), reconhecendo

\footnotetext{
a necessidade de se partir de referências teórico-metodológicas e históricas próprias, específicas para o estudo do mutualismo em um plano mais abrangente que meramente a história do sindicalismo, por exemplo. A questão da cidadania, dos movimentos sociais, na cidade e no campo, e as solidariedades horizontais se afiguram como temáticas correlacionadas de importância evidente (JESUs, 2007, p. 153).
}

Além das mutuais, outras dinâmicas associativas e de protesto permitem falar de iniciativas civis no e do século XIX. De um lado, o catolicismo tradicional, organizado àquele século em irmandades, confrarias e Ordens Terceiras, tinha fins culturais, filantrópicos e devocionais, dentre outros. Não totalmente dependente da hierarquia eclesiástica, parte importante das associações religiosas ficava sob direção de leigos; ao passo que as 'folias' e os 'reisados', menos formais que as associações, eram responsáveis pela organização de algumas festas (WERNET, 1987; FAUSTINO, 1996). Embora também se encontrem presentes na leitura do "novo associativismo", as associações religiosas, em especial as irmandades, são interpretadas, não pela sua historicidade, mas, uma vez mais, por sua homogeneidade e por aquilo que Ihes faltava, uma anacrônica "autonomia": "[as] irmandade[s] tinham como limite para a sua autonomia as limitações de uma sociedade homogênea do ponto de vista religioso" (AVRITZER, 1997, p. 156).

O estatuto analítico emprestado a esse e a outros casos é fundamental na definição daquilo que conta ou não como sociedade civil e, em alguma medida, como modernidade. Os casos de 'revolta' dos movimentos religiosos sertanejos do começo do século passado, como Juazeiro e Canudos, por exemplo, são apenas eclosões 'irracionais', 'milenaristas' e 'pré-modernas', tal como foram rotulados por boa parte das interpretações consagradas? ${ }^{7}$ É analiticamente correto e convincente reduzi-los a fenômenos

\footnotetext{
${ }^{7}$ Cf. Steil e Herrera, 2010, p. 366-ss.
} 
ideológicos ou epifenômenos de classe? $?^{8}$ As respostas a esses questionamentos importam, pois elas estão perpassadas por eixos como urbano/rural e tradição/modernidade, que, com maior ou menor grau de explicitação, também definem a origem da nossa vida civil e sua possível datação histórica. Seja como for, a eclosão de protestos no Brasil não esperou o século XX para tomar fôlego: a Revolta do Vintém, de 1880, encarnou uma das faces da crise política imperial, antecipando a Revolta da Vacina (1904) e compartilhando com ela uma lógica de expansão e confronto, com implicações fatais. Em ambos os casos, veem-se "limites fortemente marcados, para além dos quais não era permitido ao Estado, seja monárquico ou republicano, avançar sem que provocasse movimentos coletivos de protesto" (JESUS, 2006, p. 84). Esses casos levantam outro eixo caro a qualquer definição de sociedade civil, a saber, legítimo/ilegítimo. As reações populares tanto à taxação como à vacinação ilustram a negociação, talvez não densa e "emergente", mas certamente ativa e insurgente dos termos do contrato socioestatal, no qual pesou o "entendimento implícito sobre o que constituía legítima interferência do governo na vida das pessoas" (Jesus, 2006, p. 83; grifo no original).

Ainda de um ponto de vista mais exigente, seria possível encontrar formas de associativismo orientadas para incidir nas instituições políticas e na formação de opinião, como mostrado emblematicamente pelo movimento abolicionista. Embora credite ao abolicionismo o lugar de primeiro representante duma "esfera societária" no Brasil, a análise do "novo associativismo" acaba por "demonstra[r] o baixíssimo impacto institucional do movimento abolicionista" (AVRITZER, 1997, p. 158). Em oposição a essa interpretação e àquilo que chama "tese do insolidarismo", quer dizer, contra a suposta falta de densidade associativa que nos afligiria, Angela Alonso (2011) argumenta persuasivamente que a luta pelo fim da escravidão se sustentou num "associativismo avant la lettre" . A evolução das associações abolicionistas the permite dizê-lo: após o discreto surgimento das primeiras associações contra o tráfico de escravos em meados dos anos 1840, o movimento abolicionista registrou seu primeiro boom associativo entre 1868 e 1871, entre a irrupção da crise política imperial e a promulgação da Lei do Ventre Livre. No imediato pós-Ventre Livre, os grupos pró-abolição param de crescer, voltando, porém, a se multiplicar exponencialmente a partir de 1878 , com a subida dos Liberais ao poder.

Longe de responder a uma determinação partidária, jurídica ou político-institucional, essa variação observada na composição do associativismo abolicionista pode e, a nosso ver, deve ser entendida em função dos seus modos e chances de interação com atores do sistema político - assunto que ocupa o contra-argumento a seguir e por ora apenas mencionado. Um complexo arco de alianças partidárias não restrito a Liberais: brokers cruzando espaços de classe e alinhando ativismo parlamentar

\footnotetext{
${ }^{8}$ Cf. Giumbelli, 1997. Com efeito, ao escrutinar as análises clássicas que tomam como objeto aqueles movimentos religiosos sertanejos, a reflexão de Giumbelli vai além da crítica à redução classista e/ou ideológica e questiona o desligamento e a oposição indevidos entre política e religião, operados por tais análises ou nelas implícitos. Em plano analítico, o corolário dessa crítica é o abandono de noções como messianismo e banditismo, usadas à exaustão e assentadas em disposições cognitivas que fazem da religião o outro da política, apenas teórica e artificialmente externo a ela.

${ }^{9}$ Aqui nos concentramos no movimento abolicionista como instância contra-argumentativa a respeito do caráter mutuamente constitutivo entre Estado e sociedade civil. No entanto, e no detalhe, a análise de Alonso permite também uma crítica à ideia criacionista do "pluralismo" e à falta dele imputada ao passado. Enquanto associativismo avant la lettre, o abolicionismo incorporou mulheres e organizações de mulheres entre suas associações - fato conhecido por L. Avritzer, que, contudo, desconhece a pluralidade do movimento, que tinha alcance nacional e perfil multiocupacional e policlassista (ver Alonso, 2011).
} 
GURZA LAVALLE, A.; SZWAKO, J. Sociedade civil, Estado e autonomia: argumentos...

e societário; demonstrações públicas de merecimento e conquista da liberdade; crises internas à elite política percebidas e aproveitadas pela militância; um longo ciclo de protestos entre 1883 e 1884 ; e, mesmo, um projeto de lei do Ventre Livre avant garde (ALONSO, 2011, p. 190-ss.). Tudo isso é expressão de como as interconexões e interações socioestatais não esperaram o século XX e, menos ainda, um regime democrático para tomar corpo. E mais: a nuançada observação das relações entre dinâmica institucional e ativismo abolicionista permite ver como dinâmicas oficiais de nomeação de lideranças civis, já no XIX, transformam, a um só tempo, a composição da institucionalidade e as respostas civis a ela - claro exemplo de uma análise passível de ser chamada de interacionista, pois privilegia não as instituições e sequer as associações isoladamente, mas as relações entre umas e outras ${ }^{10}$.

Por fim, cabe observar que são cognitivamente empobrecedores os efeitos de uma concepção apenas sistêmica de modernidade, concepção subjacente ao diagnóstico da emergência tardia da sociedade civil. Isso é mais evidente no argumento do "novo associativismo", segundo o qual teria cabido às lojas maçônicas, tanto na América espanhola como na portuguesa, o primeiro impulso de um "padrão moderno de associativismo", "mas a ação dos seus participantes não se pauta por um padrão laico e pluralista" (AVRITZER, 1997, p. 156). Um porém a mais na conta da suposta "debilidade": a maçonaria, no caso brasileiro, além de ser contígua ao imperador, não abriu mão de filiação religiosa (p. 156). Aos maçons de outrora, teria faltado laicidade e, por extensão, ação e autocompreensão modernas.

Do ponto de vista da experiência dos sujeitos, porém, a vida moderna pode ser também definida por seu caráter dissolvente; ela dissolve certezas, divisões e hierarquias antes vividas como algo sólido, imutável e inquestionável. Assim, uma vez observado com olhos menos anacrônicos, e visto a partir dos discursos e grupos religiosos ou de outra índole em meio aos quais estava imersa a maçonaria, o Brasil da segunda metade do XIX mostra uma pugna, não menos moderna pela própria 'modernidade', contra ela e a seu favor. Mesmo sem a vida de corte e longe de se parecer com as vibrantes Salvador e Recife, a São Paulo do Segundo Império também teve de encarar o "dilema da modernidade" (FAUSTINo, 1991). Dilema não, dilemas, no plural, dado que eram muitas as polêmicas, sobre a liberdade de ensino, a emancipação feminina e a escolha entre monarquia ou república, para não falar nos espinhosos temas do padroado e da escravidão, que se impunham aos vários grupos - todos (inclusive maçons, anticlericais e até ateus ${ }^{11}$ ) autodeclarados 'católicos', mas em nada homogêneos. Na nuançada miríade de opiniões e correntes religiosas, mais próximas, mais distantes ou mesmo desligadas da hierarquia eclesiástica, digladiavam católicos 'iluministas' e 'ultramontanos'. Saudoso do "bom tempo da Idade Média" (FAUSTINo, 1991, p. 35), o ultramontanismo se opunha à maçonaria e ao 'demônio' que, a seu ver, “coordenaram um processo gradual de enfraquecimento e destruição de todos os valores cristãos da sociedade” (p. 36). Tempo de 'destruição' das certezas herdadas, de questionamentos e embates erigidos, por exemplo, pela defesa maçônica do casamento civil ou pelas representações da corrente iluminista em favor da liberdade de culto e do ensino laico... No centro

\footnotetext{
10 Note-se, porém, que os discursos abolicionistas não ficaram desconectados das fazendas e mesmo das senzalas. Sobre o caráter popular e rural do abolicionismo, ver Machado (2010).

11 Veja-se: “Enquanto o 'país legal' [...] se declarava católico, o 'país real' movia-se inteiramente à margem da fé romana. (BARROS, 2004, p. 373). [...] Era católico o maçom, católico se considerava até o anticlerical (p. 375). [...]. Pergunte-se aos ateus da representação nacional o que são - escrevia em 1874, no auge da questão religiosa, Saldanha Marinho - e eles responderão submissos: católicos, apostólicos, romanos" (p. 376).
} 
desses embates estão três bases distintivas da vida moderna: o peso da incerteza, a oposição tradicional/moderno, bem como a negação seja do 'atraso', encarnada nos discursos iluministas e maçônicos, ou das 'modernices', como no caso da reação ultramontanista. Apreendido então em seus matizes e cruzamentos culturais, doutrinários e ideológicos, o XIX desencoraja leituras de uma "sociedade homogênea do ponto de vista religioso" (cf. Avritzer, 1997, p. 156) e aponta para debates e embates, para polêmicas, opiniões e ideias (não restritas à religião) em pleno vapor.

A depender da diferenciação entre Estado e sociedade como marca distintiva da sociedade civil, todos esses exemplos dão notícia de um século XIX civilmente muito mais organizado e agitado do que aquele comumente imaginado. Agitação e organização obliteradas pelo efeito de teoria que ilumina não a especificidade, aquilo que existe, opera e precisa ser compreendido, mas aquilo que não há: a falta - de diferenciação, pluralidade, autonomia, densidade associativa ou laicidade - reveladora daquilo que não fomos $^{12}$. Tal diferenciação, no entanto, não deve ser tomada como expressão analítica de uma separação, de uma dicotomia. Ao contrário, tal como desenvolvemos logo a seguir, Estado e sociedade civil se constituem mutuamente; o que importa, segundo as lentes analíticas da mútua constituição, é explicar o conjunto de dinâmicas, padrões, encaixes e lógicas que configuram um modo recíproco de constituição socioestatal tendencialmente estável, porém historicamente mutável. No que se segue, o contra-argumento permitirá reconstruir algumas das fontes teóricas de inspiração que informam uma abordagem centrada nas relações e continuidades, e não na separação, entre Estado e sociedade civil, de modo a enfatizar a codeterminação entre eles.

\section{A autonomia e o advento da interdependência entre sociedade civil e Estado}

Os reclamos de 'autonomia' em relação ao Estado, aliados ao surgimento 'inédito' de atores sociais modernos, teriam sido a marca distintiva dos anos 1970 e 1980 ou, com maior precisão conforme a periodização de L. Avritzer da primeira etapa -, de 1977 a 1985 (AvRITZER, 2012, p. 390). Atores populares mobilizados pela demanda de serviços públicos, associações profissionais de classes médias críticas perante políticas setoriais autoritárias e/ou ineficientes e setores liberais oriundos das mesmas classes confluíram na configuração da "emergência da sociedade civil" sob o signo comum da "autonomia" (p. 386-ss.). Com efeito, "a principal característica da sociedade civil durante esse primeiro período foi a reivindicação de autonomia em relação ao Estado" (p. 389) ${ }^{13}$. O sentido do "movimento pela autonomia social" seria profundamente radical, como atestado por aqueles que L. Avritzer identifica como seus dois significados principais, a saber, autonomia organizacional em relação ao Estado e a defesa de "formas de administração de políticas sem a participação do Estado [...] ou de que a sociedade civil podia lidar com políticas públicas de forma independente do Estado" (p. 389-390). A caracterização daquele momento sob o signo da 'autonomia' é ponto comum nas literaturas dos anos

\footnotetext{
12 A tarefa de criticar os efeitos de categorias negativas e ou diagnósticos em negativo, centrados na denúncia da falta, já foi realizada alhures, no plano ideacional ou do registro do pensamento político-social no Brasil (cf. Gurza Lavalle, 2004).

$13 \mathrm{O}$ autor menciona em uma frase que os reclamos de 'autonomia' também eram em relação a partidos políticos, mas essa única menção não tem desdobramentos na caracterização da "autonomia", descrita apenas em relação ao Estado. Para uma análise cuidadosa do papel dos partidos políticos nos escritos do Avritzer, ver Romão (2011).
} 
GURZA LAVALLE, A.; SZWAKO, J. Sociedade civil, Estado e autonomia: argumentos...

1980 e 1990, debruçada sobre o papel dos atores sociais na redemocratização brasileira e, especificamente, dos movimentos sociais (cf. Chaui, 1988; Sader, 1988; Paoli, 1995) e da sociedade civil (cf. Gohn, 1997); o corolário dessa caracterização enfática da 'autonomia' no diagnóstico de conjunto aqui examinado é, previsivelmente, o advento da interdependência política.

Espanta a possibilidade de pensar autonomia como ausência de relação entre atores sociais e Estado. No plano da teoria, as interações e a mútua constituição entre interesses sociais organizados e Estado definem o âmago da construção da ordem política em si (SKOCPOL, 1992, p. 41.62), e não as feições emergentes de um período histórico antecedido por um momento de 'plena autonomia' da sociedade civil - o que pressuporia também a 'autonomia pura' do Estado em relação aos atores sociais nem, necessariamente, a distinção entre regimes democráticos e não democráticos. Mesmo no contexto das ditaduras latino-americanas, as instituições do Estado não pairavam no ar, sem bases sociais ou resguardadas por uma autossustentação hermética (veja-se, dentre outros, Rollemberg; Quadrat, 2010).

Mais de uma postura teórica privilegia a interdependência ou as interações entre sociedade civil e Estado como foco analítico. Na América Latina, as compreensões da sociedade civil de matriz gramsciana desempenharam papel importante na crítica à compreensão dicotômica da relação entre Estado e sociedade civil (DAgnino, 2011; DAgnino, Olvera; PANFICHI, 2006) ${ }^{14}$. As tradições do neoinstitucionalismo histórico e da macrossociologia histórica comparativa, por sua vez, produziram análises primorosas de processos de longa duração a respeito, por exemplo, da gênese das bases da cidadania moderna graças à resistência das comunidades à exação de recursos pelo soberano - como a conscrição compulsória do filho primogênito -, ou a respeito do surgimento dos impostos como forma abstrata de solidariedade, ou, ainda, acerca da proliferação exitosa do Estado-nação sobre sultanatos, principados, bispados, e uma miríade de soberanias que povoaram secularmente a geografia política europeia (TILLY, 1996; BENDIX, 1996). Essas tradições também geraram análises de processos de duração média como a construção dos sistemas nacionais de saúde na Europa (IMMERGUT, 1992) ou o despertar associativo nos anos posteriores à guerra civil norte-americana (CROWLEY; SKOCPOL, 2001), e inclusive as próprias transições políticas na América Latina (COLLIER; COLLIER, 1991) - para citar apenas alguns trabalhos emblemáticos de um campo em franca expansão durante as últimas décadas (MAHONEY; RUESCHEMEYER, 2003).

No caso dos neoinstitucionalistas, a tese da mútua constituição entre Estado e sociedade civil significou, já no começo dos anos 1990, um afastamento ante posturas State-centered e sua excessiva ênfase na autonomia das políticas ${ }^{15}$ - ênfase própria da primeira geração que trouxe 'the State back in'. Ela levou ora a abordagens centradas na influência institucional do Estado sobre a disposição a agir e as capacidades de ação dos atores sociais, ora a examinar a construção histórica dessas capacidades em termos, por exemplo, da moldagem de encaixes institucionais (institutional fit) ou entradas preferenciais

\footnotetext{
14 Para uma avaliação crítica do diagnóstico de L. Avritzer aqui abordado e de seus fundamentos teóricos, ambos de uma perspectiva gramsciana, ver Burgos (2014).

${ }^{15} \mathrm{Cf}$. "[The analysis] suggests that the stark dichotomy between state and society often drawn by state-centric theory should be revised in order to allot a significant role to the political system, defined as the complex of political parties and interest intermediaries that stand at the intersection between the state and society in democratic polities. [...] [It also] indicates that we need an even more expansive concept of state-society relations than such traditional conceptions of the political system provide. [...] [W] hile recognizing the usefulness of 'bringing the state back in', this analysis cautions us against positing too rigid a distinction between the state and society and against an insistence on the autonomy of the state" (HALL, 1993, p. 288; 292).
} 
(engeniering fit) dos atores sociais no Estado (SKOCPOL, 1992, p. 47-54). Quanto aos pressupostos teóricos, o neoinstitucionalismo histórico opunha-se a macrointerpretações de classe ou de fundo modernizante para explicar as políticas de welfare; já no nível de suas implicações para a ação coletiva, esse debate se voltou criticamente para os autores dos movimentos sociais na vertente do processo político. Contra estes, E. Amenta et al. (2002) argumentaram que o Estado permanece infrateorizado pela contentious politics e que noções como "oportunidade política" tendem a repor a dicotomia entre atores estatais e não estatais. Como corolário, a crítica levou seus autores a forjar o modelo da "mediação política" (AMENTA et al., 2005) e a questionar quais variáveis propriamente institucionais explicam o impacto dos movimentos sobre a institucionalidade (AMENTA et al., 2010). Por outro caminho, igualmente fértil, E. Clemens se dedicou aos encaixes socioestatais, partindo, porém, de uma dimensão negligenciada nos estudos dos movimentos: a sua lógica organizacional. Essa autora se volta para as inovações no "repertório organizacional" de mulheres estudadas por Skocpol, bem como para os efeitos dessas inovações na interação com o arcabouço institucional político estadunidense (CLEMENS, 1993). Amenta e Clemens não dão apenas pista de como avançar nos estudos sobre impactos político. institucionais dos movimentos e de suas interações; a nosso ver, suas análises também encarnam de modo profícuo as implicações teórico-analíticas da tese da constituição recíproca entre Estado e sociedade civil, em sua versão e inspiração neoinstitucionalista.

Se no debate anglo-saxão foi o caráter autônomo (ou não) das políticas ou da política no Estado que pautou uma parte da discussão, na literatura brasileira, foi a autonomia dos atores sociais que deu (e ainda parece dar) o tom do debate. O estatuto teórico da categoria autonomia é crucial - e nossa interpretação sobre ela será retomada adiante, no último contra-argumento -, mas, por ora, importa assinalar duas razões históricas, não inscritas no plano da teoria, que podem animar a descrição dos anos 1970 e 1980 como um 'momento de autonomia', a saber, as descrições coevas disponíveis na literatura e a narrativa dos atores preservada em registros de época ou mediante rememorações posteriores. Ambas as razões, conforme será visto logo a seguir, comparecem ao diagnóstico enfático da autonomia. No que diz respeito aos atores, a experiência de um Estado autoritário e iníquo nos terrenos tanto da contestação política quanto da definição e implantação de políticas públicas teria produzido duplo efeito: o 'surgimento' ou 'criação' da sociedade civil em reação às circunstâncias e a ênfase em uma autonomia 'radicalizada' em relação ao Estado. Assim, associações mobilizaram-se desenvolvendo novos repertórios de ação independente, e atores, como o movimento sanitarista, foram além ao propor "a organização de serviços de saúde independentes do Estado" (AvRITZER, 2012, p. 389). Por sua vez, a literatura sintonizada com o debate internacional e sensível aos reclamos de 'autonomia' teria passado a utilizar a categoria sociedade civil, que pela primeira vez faria sentido cabal na história do país.

Sem dúvida, nesses anos a autonomia encontrava-se instalada tanto como categoria prática, a significar o sentido da ação dos atores, quanto como categoria teórica, a orientar os esforços cognitivos e compromissos normativos dos autores, mas a positivação de ambos os elementos em nossa compreensão contemporânea do período não apenas é operação mui seletiva, mas conduz a um diagnóstico autonomista - factualmente incorreto. No que diz respeito à literatura, muito devemos aos trabalhos dos anos 1980 que inovaram intelectualmente e sintetizaram a riqueza desse momento 
histórico (BRANT et al., 1982; DoImo, 1984; SADER, 1988) ${ }^{16}$; entretanto, pouco honramos o espírito intelectual dessa geração ao repetir diagnósticos ipsis litteris mais de 20 anos depois, ainda mais quando considerado que os próprios integrantes dessa geração fizeram balanços coetâneos sugerindo correções ao que julgaram ser custos cognitivos do espírito da época. Nas palavras de R. Cardoso (1983):

\footnotetext{
o processo de mobilização popular aparece, nestas interpretações, como resposta espontânea ao autoritarismo e à incompetência dos governos. Neste quadro, a atenção dos cientistas se volta para este sentimento 'oposicionista-democrático' das massas urbanas e deixa na sombra a atuação do Estado (CARDOSo, 2008, p. 319) ${ }^{17}$.
}

A literatura da época não apenas foi sensível à 'autonomia' como categoria prática dos atores, mas encontrava-se inscrita na disputa pela democratização do país e, por isso, comprometida com as implicações políticas da linguagem dos atores e vocacionada a orientar a realização de tais implicações. Hoje é possível apreciar o valor dessa literatura, bem como entender os motivos que animaram a proximidade entre a linguagem da teoria e a linguagem prática dos atores; não obstante, não mais parece prudente assumir as narrativas herdadas desse momento. Trabalhos mais recentes, dedicados a revisar o período com minúcia, têm mostrado o quanto essa narrativa é datada e requer correções (ASSIES, 1991; HOUTZAGER, 2004; IFFLY, 2010; DOWBOR, 2012; CARLOS, 2012).

A autocompreensão dos atores, bem como a significação das suas práticas e narrativas mediante a invocação da 'autonomia', poderia ser utilizada como evidência empírica para a caracterização dos anos 1970 e 1980 como um período de 'radicalização da autonomia' em relação ao Estado. De fato, o movimento sanitarista é citado como caso emblemático de mobilização e recebe especial atenção no diagnóstico de conjunto aqui examinado por ter "radicalizado a ideia de autonomia social" (AVRITZER, 2012, p. 390) ao propor "a organização de políticas públicas independente do Estado" (AVRITZER, 2012, p. 389).

A mobilização das evidências para sustentar tal compreensão, todavia, precisa ser espantosamente seletiva. O movimento sanitarista encontrava-se em processo de formação na segunda metade dos anos 1970 (ESCOREL, 1998) e, conforme mostrado no estudo de Dowbor (2012), já nesse momento definiu uma estratégia de atuação prioritariamente centrada em dois flancos, a qual viria a se tornar perene. Primeiro, o "caminho institucional denominado pelos atores de 'ocupação de espaços no Estado'” ou, para dizê-lo em palavras nativas comuns à época, 'a entrada no coração do sistema' (DowBOR, 2012, p. 107). Essa linha de atuação foi amplamente debatida e tornou-se prática comum na forma de ocupação de cargos e de uso dos recursos associados a esses cargos para promover o ideário da medicina social - mediante o desenho e a implementação de programas públicos, por exemplo - e a organização e a mobilização do próprio movimento sanitarista. O segundo flanco de atuação visou a construir o campo profissional da medicina social, mediante a criação de instituições de ensino e

${ }^{16}$ Sínteses ricas e sintonizadas com o debate dos anos 1980 continuaram a ser publicadas durante a primeira metade dos anos 1990, conforme atestado pelo influente trabalho de Doimo (1995) sobre a trajetória dos movimentos sociais no pós-1970.

17 Ver também Machado da Silva e Ribeiro (1985). 
pesquisa, a definição de curricula e a regulação da profissão. Em ambos os casos, a estratégia bem. sucedida do movimento sanitarista não apenas pressupôs interação com o Estado, como também disputa dentro do Estado pelas políticas e capacidade regulatória do próprio Estado.

Os atores do período falaram de 'autonomia' e procuraram significar suas práticas invocando-a. A compreensão dos sentidos da 'autonomia', todavia, é tarefa árdua que demanda o exame das situações em que ela é invocada por diferentes atores, de modo a desvendar os sentidos atualizados por tal invocação perante diferentes interlocutores. Seus sentidos, por conseguinte, não podem ser derivados da teoria, nem imputados em macronarrativas de modo homogêneo à sociedade civil como um todo. Isso coloca o problema da relação entre pesquisa empírica, categorias nativas ou práticas e categorias teóricas, o qual será retomado no último contra-argumento. Como já observado, porquanto sociedade civil e Estado são mutuamente constitutivos, a invocação da 'autonomia' não implica ausência de interação - conforme mostrado acima no caso do movimento sanitarista -, da mesma forma que sua não invocação tampouco implicaria submissão ao Estado ou qualquer forma de fusão com ele. Esse é um bom ponto de partida para se afastar tanto dos diagnósticos de 'insolidarismo' (cf. Alonso, 2011), típicos das interpretações da sociedade civil no século XIX, quanto do argumento do autonomismo e sua leitura da separação dicotômica entre Estado e sociedade civil no período do governo militar.

\section{O pós-1988 e o esvaziamento da interdependência entre Estado e sociedade civil}

O período "radicalizado" (AVRITZER, 2012, p. 390) e autonomista teria sido sucedido por uma nova fase, demarcada com precisão cronológica em 1987 graças à Constituinte, mas com desdobramentos duradouros que reforçaram transformações na "autonomia" dos atores sociais transformações desencadeadas no momento da própria Assembleia. Com efeito, "existe um divisor de águas entre a reivindicação de autonomia do Estado nesta primeira fase (1977-1985) e a reivindicação de autonomia durante a segunda fase (1985 até hoje): a Assembleia Nacional Constituinte" (p. 390) e, como decorrência, a inauguração de uma nova fase chamada de "aprofundamento democrático" (AVRITZER, 2012, p. 387, 390). A chave para entender o papel de divisor de águas da Constituinte reside nas emendas populares e as dezenas de milhares de assinaturas que as apoiaram como estopim - ou "primeiro momento" (p. 390) - de aprofundamento democrático responsável pela ampliação de direitos sociais (saúde ou reforma urbana) e políticos (instituições participativas em diversas áreas e setores de políticas públicas). As mudanças na "autonomia" seriam, nesse sentido, resultado do sucesso da ação da sociedade civil, e, por isso, o "movimento pela autonomia social não sobreviveu à democracia com a mesma concepção com que surgiu" (p. 386). Quiçá um terceiro fator, mencionado apenas en passant e sem qualquer desdobramento no argumento, poderia ter contribuído para a transformação da autonomia, a saber, as "reformas neoliberais [que] interagiram com as responsabilidades dos atores da sociedade civil nas políticas públicas” (p. 387). Assim, L. Avritzer oferece diagnóstico alternativo àquelas leituras críticas que, partindo de um 'totalitarismo neoliberal' (OLIVEIRA, 2000), identificaram uma sorte de hiperdesmobilização, isto é, "uma ordenação que consegue impedir que se formem experiências e 
GURZA LAVALLE, A.; SZWAKO, J. Sociedade civil, Estado e autonomia: argumentos...

comunidades políticas capazes de aparecer como tal" (RIzEK; PAOLI, 2007, p. 10) ${ }^{18}$. Seja como for, na nova fase a sociedade civil teria se tornado "mais ou menos autônoma vis-à-vis o Estado" (p. 387).

Ao mesmo tempo em que firmou um retrato da sociedade civil sem interdependência com o Estado, a caracterização do período anterior associou algumas das virtudes da mobilização social e a própria emergência da sociedade civil em si a uma genuína 'autonomia' em relação ao Estado. Dado esse diagnóstico enfático, a aparição da interdependência com o Estado poderia trazer consigo consequências corrosivas para a recém-emergida sociedade civil. Pois bem, na etapa do aprofundamento democrático, a sociedade civil cresceu e viu ampliar sua influência política seguindo "uma lógica mista entre autonomia e dependência" (AvRITzer, 2012, p. 393). Prova cabal dessa lógica mista seria a composição da sociedade civil no Brasil, alicerçada em dois grandes grupos de associações: o primeiro, mais estável, de base religiosa, vinculado a setores populares e - presumivelmente - 'autônomo', enquanto o segundo, ligado ao Estado pela implementação de políticas públicas, inscrito na órbita da esquerda e das lutas pela democratização e, por conseguinte, interdependente. "Nesse sentido, o argumento para uma completa interdependência entre sociedade civil e Estado parece não se sustentar" (AVRITZER, 2012, p. 394). As evidências empíricas aí mobilizadas são intrigantes, mas não há espaço nestas páginas para um exame cuidadoso delas ${ }^{19}$. Aqui interessa atentar para o esvaziamento da noção de interdependência e suas consequências sobre o diagnóstico do pós-1988; quer dizer, atentar para o cerceamento do alcance heurístico da interdependência e para as limitações explicativas desse diagnóstico que, em sua vontade de salvaguardar a autonomia, sai do truísmo (há interdependência) para recair numa aporia (uma sorte de interdependência sem dependência).

A ideia de que a "completa interdependência" compromete a autonomia dos atores sociais deriva de um entendimento autonomista (não relacional) da segunda. Seja como for, tornar a autonomia e a interdependência atributos de conjuntos de atores específicos - respectivamente, das associações religiosas e das associações voltadas para a implementação de políticas -, em vez de um continuum presente nas práticas de todo ator da sociedade civil e em diferentes momentos, é operação analítica tão implausível quanto a separação da trajetória da sociedade civil no Brasil em dois períodos demarcados pela passagem da 'autonomia plena' para a interdependência em relação ao Estado. Desde perspectivas relacionais ou centradas na codeterminação entre Estado e sociedade civil, como aquela assumida aqui, distinguir esse momento histórico pelo caráter interdependente dos laços socioestatais é um truísmo, e por isso um diagnóstico bastante frágil, visto que - seja em períodos autoritários ou democráticos ambos se constituem reciprocamente. Mais: aceitar a interdependência para, em seguida, lançar mão de operação analítica para the aparar as implicações indesejáveis esvazia essa categoria de seu potencial heurístico. Seguindo boa parte da sociologia histórica, é sabido que as redes e os laços de interdependência, seja entre indivíduos, entre grupos, entre classes ou entre Estados-nação, são

\footnotetext{
18 Para uma revisão crítica dessa produção, ver Szwako (2009).

19 L. Avritzer formula um diagnóstico da composição da sociedade civil no Brasil a partir de um survey aplicado a cidadãos em São Paulo. A unidade empírica dessa composição são associações, e proposições sobre sua composição e evolução no tempo no país demandam dados sobre associações e com cobertura nacional. Entrementes, tal diagnóstico descansa em dados sobre indivíduos e sua participação em associações em uma cidade. Uma análise cuidadosa desse diagnóstico teria de mostrar os custos cognitivos de derivar proposições acerca de um plano organizacional (a composição da sociedade civil) de evidências sobre as práticas de participação de indivíduos.
} 
condição constitutiva das configurações sociais e de suas mutações (ELIAS, 1993; 1994). Heuristicamente fértil, essa fonte específica de interpretação histórico-sociológica tem inspirado críticas a concepções dicotômicas e maniqueístas do par Estado/sociedade civil e às 'essências' (respectivamente, negativa/positiva) imputadas aos polos desse par (SILVA, 2006). Embora possa estar ligada a alguma idealização do polo civil, a caracterização do pós-1988 parece antes um empenho em manter teoricamente imaculada a "autonomia" da sociedade civil e de seus atores: "[a sociedade civil] interage com o Estado mantendo a sua própria dinâmica organizacional e o seu próprio processo de tomada de decisão" (AVRITZER, 2012, p. 386; ênfases acrescidas). Em outras palavras, a sociedade civil interage, mas não se implica; interdepende, mas não depende; interage, retomando M. Silva, sem perder sua (suposta) essência. Cognitivamente enraizado no autonomismo, o diagnóstico da nova fase como um período em que a sociedade civil é "mais ou menos autônoma" veicula uma contradição em termos: uma interdependência sem dependência.

Se, no plano analítico, a interdependência não guarda relação exclusiva com a dependência, nem excludente com a autonomia, mas supõe ambas, e se, no plano empírico, a expansão quantitativa e qualitativa das chances e dos modos de acesso civil ao Estado é traço distintivo do "aprofundamento democrático", esse cenário não pode ser analisado por parâmetros que, declaradamente ou não, atribuem sinal negativo a essas e outras formas de aproximação socioestatal. A nosso ver, é possível prescindir da caracterização autonomista da sociedade civil dos anos 1970 e 1980, bem como da tese de um divisor de águas que teria inaugurado uma fase de interdependência, e ainda reconhecer a existência de transformações de vulto nas relações entre atores estatais e civis. Para perspectivas que assumem o caráter mutuamente constitutivo da relação entre Estado e sociedade civil - conjugando em graus variáveis autonomia e dependência -, o diagnóstico do pós-1988 como marcado pela "semiautonomia"20 acaba onde deveria se iniciar, isto é, na afirmação da interdependência. Por confundir um processo histórico com aquilo que é sua condição, ou seja, ao nomear e distinguir o processo pós-1988 por seu caráter “interdependente", o diagnóstico resta vazio, pois pensa ter explicado o cenário recente através da evocação da "interdependência", quando, na verdade, deixa sem explicação as lógicas, os padrões de interação e os (des)encaixes operantes entre Estado e sociedade civil, que, afinal, dão carne e osso àquele cenário transformado, porém sempre interdependente.

O desafio é, na nossa compreensão, documentar extensivamente as diversas modalidades de interdependência que ocorrem em diferentes interfaces socioestatais (ISUNZA, 2006; ISUNZA; HEVIA, 2006; GURZA LAVALLE; ISUNZA, 2010); identificar padrões pretéritos de interdependência entre atores sociais e Estado, diagnosticar padrões emergentes e se debruçar sobre as consequências dessas transformações. Diversas pesquisas têm encarado os desafios impostos por dinâmicas de institucionalização não só da sociedade civil e de interfaces socioestatais, mas também das demandas dos atores da primeira vis-à-vis autoridades públicas. E. Carlos (2012), por exemplo, debruça-se sobre os efeitos da institucionalização

20 "Semiautônomo" é adjetivo que L. Avritzer retoma de Cornwall e Coelho (2007), mas é por elas utilizado de modo distinto. Para as autoras, não é a sociedade civil que tem caráter "semiautônomo", mas as instituições da chamada "esfera participativa"; "The institutions of this sphere have a semi-autonomous existence, outside and apart from the institutions of formal politics, bureaucracy and everyday associational life, although they are often threaded through with preoccupations and positions formed in them" (CORNWALL; COELHO, 2007, p. 1-2). 
GURZA LAVALLE, A.; SZWAKO, J. Sociedade civil, Estado e autonomia: argumentos...

da participação sobre os movimentos sociais, e oferece um diagnóstico segundo o qual, pari passu às transformações e interações socioinstitucionais, produzira-se um padrão de ação coletiva em que são combinadas, de modo não contraditório, estratégias de cooperação e enfrentamento. Já a partir do caso do movimento da Economia Solidária, M. Silva e G. Oliveira (2011) demonstraram como as estratégias do movimento passam tanto pelo trânsito de atores rumo ao Estado, conformando uma interseção com ele, quanto por relações de interpenetração com partidos, no caso, de esquerda. Em chave semelhante, a aproximação Estado/movimentos e as implicações de tal aproximação constituem, para Teixeira e Tatagiba (2005), os "desafios da participação". Em sua análise a respeito da participação na capital paulista, essas autoras notaram não só que os canais participativos são uma estratégia-alvo no rol mais amplo de estratégias de acesso ao Estado, mas também que os sentidos da 'autonomia' se transformam nesse rol e em função da posição institucional (executiva ou legislativa) dos interlocutores dos movimentos analisados. No entanto, a tática de aproximação ao Estado não é dinâmica exclusiva do pós. 1988, e a esse respeito vale lembrar a trajetória do movimento pela Reforma Sanitária, que conseguiu imprimir seu projeto de universalização da saúde como direito do cidadão e dever do Estado, não a despeito deste, mas através da ocupação e da permanência em suas instituições (DoWBOR, 2012).

Por vias distintas, mas com pontos de chegada bastante análogos, outro grupo das pesquisas recentes tem se dedicado à compreensão do impacto dos encontros e desencontros entre sociedade civil e Estado sobre este último. Em diálogo crítico com a literatura participacionista brasileira e internacional, Abers e Keck (2009; 2013) examinam a "mobilização do Estado" pela sociedade civil e argumentam que a atuação de atores não estatais nos comitês de gestão de água não se restringe à deliberação e ao controle do Estado; esses atores podem, diante de limitações de operação do Estado, fortalecer o próprio Estado em nível organizacional ou técnico, para levar a cabo seus interesses nos comitês analisados. Por outra via, em diálogo com o institucionalismo histórico, Szwako (2013) demonstra como o recente incremento da política de saúde, no caso paraguaio, passa necessariamente pela interação da burocracia ministerial com atores não estatais, sejam eles civis ou de agências internacionais. Registro semelhante é adequado para compreender a política de habitação e sua relação com os atores e as demandas históricas do movimento pela reforma urbana durante os governos de Lula, conforme mostrado pela análise de Serafim (2013) da burocracia ministerial da área. Nas três análises, o deslocamento analítico operado sai duma chave participacionista/acionalista de interpretação, para enfatizar aquilo que pesa institucionalmente nas interações socioestatais. Tal deslocamento, por sua vez, tem implicações que obrigam a se desfazer de fatores explicativos de tom maniqueísta - dos quais o mais recorrente é a vontade política (RoMÃo, 2011; SOUZA, 2013) - e a trazer para primeiro plano o peso das variáveis institucionais para além do desenho institucional como, por exemplo, a capacidade estatal (inclusive a falta dela e a sua transformação), tomando-as como dimensão estruturante dos encaixes socioestatais e dos efeitos institucionais produzidos pelos 'erráticos' encontros entre atores estatais e não estatais.

Esse cenário, no qual se multiplicam as interações socioestatais institucionalizadas, demanda categorias de médio alcance capazes de iluminar e apreender as lógicas e dinâmicas operantes entre Estado e sociedade civil. Com esse perfil, a categoria mais influente na literatura brasileira e latino. 
americana é "projeto político", cunhada na tradição gramsciana por Evelina Dagnino (DAGNINO; OLVERA; PANFICHI, 2006). Além de pressupor o caráter heterogêneo dos atores civis e estatais, o uso sistemático e reconstrutivo da categoria projeto político desfaz o artificialismo da oposição entre Estado e sociedade civil, dando vez aos modos e fins transversais pelos quais autoridades e atores civis se vinculam estrategicamente. Outra distinção analítica intermediária é o chamado "domínio de agência" (GuRZA LAVAlle; HoutZAGeR; CAStello, 2012). Em diálogo com o neoinstitucionalismo, o neocorporativismo de P. Schmitter e a literatura de ecologia organizacional, a noção de domínios de agência atenta para a construção política das capacidades de atuação dos atores da sociedade civil mediante dinâmicas de institucionalização que definem domínios de atuação legítimos para determinados conjuntos específicos de organizações civis por meio da cristalização formal de barreiras de entrada, dispositivos de acesso aos recursos estatais e reconhecimento da sua capacidade de representar determinados interesses.

Não são poucos os desafios analíticos e também empíricos postos àquelas análises que operam na perspectiva da mútua constituição entre sociedade civil e Estado e das interações entre seus respectivos atores. Os desenvolvimentos recentes da literatura acima elencados contribuem a elucidar formas, instâncias e níveis de interconexão; condicionantes institucionais que modelam a interação e o alcance político de movimentos sociais e de outros atores da sociedade civil; bem como a construção de parte das capacidades de ação do Estado - todas elas questões integrantes de uma ampla agenda interacionista de pesquisa que, a julgar pelos avanços da literatura, encontra-se em andamento. Ainda permanece em pé, todavia, o problema analiticamente mais complexo que subjaz não apenas ao diagnóstico de conjunto examinado, mas, de modo geral, às literaturas de sociedade civil e movimentos sociais.

\section{Mimesis entre a autonomia como categoria teórica e como categoria prática}

O esforço por caracterizar uma "interdependência sem dependência" leva a supor que subjazem à centralidade conferida à "autonomia" motivações teóricas substantivas. Isso coloca a questão central das diferenças e possíveis conexões entre os usos práticos e teóricos que, respectivamente, os atores e os autores fazem dela. No plano dos atores sociais, a autonomia teria sido "entendida como agir sem pedir autorização do Estado e, ao mesmo tempo, ignorar os limites colocados pelo Estado à organização interna e externa das associações voluntárias" (AVRITZER, 2012, p. 389). Já no plano da literatura, e de modo consequente com a linguagem utilizada pelos atores, "[t]eorias da sociedade civil durante o final dos anos 1980 e início de 1990 trataram as práticas de atores da sociedade civil em termos de autonomia" (AVRITZER, 2012, p. 385). Por outras palavras, os autores teriam incorporado à literatura a categoria nativa dos atores: "o modelo de autonomia plena estava ligado à concepção dos atores e não a uma concepção normativa preconcebida" (p. 393). Entretanto, assim procedendo, o debate da época teria traduzido a literatura internacional sobre sociedade civil ante "elementos locais", aliando a "dimensão autônoma da sociedade civil" a "todos os tipos de movimentos sociais [...] e até mesmo [a] uma ideia geral de autonomia que vinha do próprio sindicalismo" (p. 386). 
GURZA LAVALLE, A.; SZWAKO, J. Sociedade civil, Estado e autonomia: argumentos...

No diagnóstico de conjunto a relação entre categorias práticas e teóricas segue a mesma lógica, a saber, a língua falada no plano da literatura é pautada ou 'inspirada' pelas falas dos atores. Assim, nos

anos oitenta no Brasil, a sociedade civil estava preocupada com a autonomia [...]. [Nos] anos noventa, a sociedade civil brasileira começou a se preocupar com o estabelecimento de uma forma mais ampla de participação pública na maioria das áreas de políticas públicas (AVRITZER, 2012, p. 392).

Logo, "autonomia", "democratização das políticas" e "controle público" - questões supostamente distintivas da década de 1980 - são "preocupações que inspiraram o marco analítico da autonomia" (AVRITZER, 2012, p. 392). Daí à “interdependência” pós-1988: "toda a literatura recente sobre a sociedade civil enfatiza as interconexões entre a sociedade civil e o Estado" (p. 392). Nessa embocadura, o plano dos debates apenas segue o plano prático dos atores civis - ambos indo "da autonomia à interdependência" - aliando essa mimese à linguagem em voga na literatura internacional. Mantém-se assim uma intimidade entre registros teórico e prático, cujas raízes históricas estruturam o campo de debate sobre movimentos sociais e sociedade civil, parte das quais foram tratadas no contraargumento anterior.

Tal indistinção analítica, que permite deslizes entre os usos teóricos e práticos da ideia de autonomia, como se se tratasse de uma mimese, não apenas presta um desserviço ao desenvolvimento de teoria ou de pesquisa empírica, como é imprecisa do ponto de vista da descrição da produção acadêmica do momento, haja vista a predominância de compreensões da sociedade civil de inspiração habermasiana ao longo dos anos 1990, a exemplo do próprio L. Avritzer (cf. 1996). Por motivos analíticos diversos, teorias podem conceder relevância à ideia de autonomia, como é sabidamente o caso das compreensões habermasianas de sociedade civil. Esses motivos são dignos de escrutínio nos seus próprios termos e no nível de abstração em que opera a teoria. Por sua vez, é inteiramente compreensível que a noção de autonomia seja cara aos atores sociais, e desvendar os sentidos a ela conferidos, como será visto logo a seguir, é desafio nada banal para a pesquisa empírica. Contudo, supor que os motivos da teoria e dos atores coincidem é uma escolha sociológica e teoricamente improdutiva, que inibe a indagação empírica porque as respostas jazem prontas no plano da teoria, e poupa o esforço conceitual de especificar as mediações que conectam as práticas dos atores significadas pelos usos nativos da noção de "autonomia" com as definições substantivas e abstratas da teoria.

No plano teórico, a autonomia pode desempenhar diferentes funções nos arcabouços analíticos em questão, bem como ser valorizada por diversos motivos. Assim, a autonomia qua categoria de análise não é unívoca e sequer autoevidente; seu uso admite uma ampla gama de filiações analíticas e, seguindo o cânone epistemológico de explicitação da posição da fala, cabe aos autores ser claros quanto a seus pressupostos teórico-normativos. Em Habermas (1987), a autonomia ocupa uma posição no plano da macroteoria da sociedade em dois níveis, cujo horizonte temporal de longa duração remete à gênese e ao desenvolvimento da diferenciação entre o mundo sistêmico - Estado e mercado - e o mundo da vida. A autonomia é, precisamente, não uma reivindicação de determinados atores em uma conjuntura específica, mas uma propriedade distintiva e constitutiva - por definição - do mundo da vida, imprescindível para a realização do seu potencial de inovação e emancipação. Assim, em registro 
habermasiano, o mexicano A. Olvera (2004, p. 24) formula com precisão que "autonomia se refere à aberta diferenciação que atores sociais fazem perante o Estado e o mercado"; tais atores sociais "não se assimilam à lógica da luta pelo poder nem se subordinam às diretrizes estratégicas dos partidos". É essa a perspectiva teórica que nos anos 1990 animou os trabalhos de L. Avritzer e de parte significativa da literatura no Brasil e na América Latina, e não espanta que seja exatamente nesses termos - embora como realização tardia da modernidade (em meados dos anos 1970) - que é descrita a 'emergência' da sociedade civil. Igualmente, é porque ecoaram nesses pressupostos que os usos nativos da noção de autonomia suscitaram atenção; pressupostos que também iluminam o empenho de L. Avritzer por definir uma peculiar interdependência sem dependência.

A autonomia pode ser uma categoria relevante em outros registros teóricos, inclusive se dedicados à teoria positiva - não normativa -, como tal, desenvolvida para orientar a pesquisa empírica. O recurso analítico à autonomia tem centralidade no pluralismo, não no terreno macroteórico da evolução social no mundo moderno, mas, conforme caracterizado por Dahl (1982), no dos dilemas que a consociação de interesses sociais coloca às democracias. A autonomia de uma associação é definida como sua capacidade de agir prejudicando os interesses de terceiros sem que eles possam impedi-lo e, por isso, o conceito é entendido como complementar ao de controle (DAHL, 1982, p. 16-22). A relação entre autonomia e controle das associações nas democracias é dilemática, pois ambos são a um só tempo desejáveis e implicam riscos. Mais: ambos os termos existem apenas em combinação e não de forma pura. Essa definição, aliás, permaneceu praticamente incólume ao longo da extensa produção do autor de Poliarquia ${ }^{21}$. Inclusive no âmbito da discussão normativa - em que abundam definições e níveis (privado e público) de escrutínio sobre suas bases (morais, individuais, coletivas ou outras) -, compreensões não macrossociais de autonomia são também possíveis. Em obra dedicada na íntegra à construção de uma teoria da autonomia moral, G. Dworkin esquadrinha o desafio de incorporar constrangimentos de índole diversa sem, todavia, cancelar a dimensão de autodeterminação nevrálgica ao conceito. A concepção de autonomia por ele trabalhada remete a "uma capacidade das pessoas de refletir criticamente sobre suas preferências, desejos e objetivos [de primeira ordem], bem como de aceitar mudá-los ou tentar mudá-los" à luz de novas informações e reflexões, ou tecnicamente, de preferências de segunda ordem (DWORKIN, 1988, p. 20). Como se nota, então, o estatuto teórico da autonomia é diverso e segue a variedade nuançada dos debates, registros e problemas de pesquisa e desenvolvimento conceitual nos quais ela pode ser acionada, mas não como mimese da fala dos atores.

Porém, no plano empírico permanece em pé a questão de como lidar com a autonomia como categoria prática relacional, quer dizer, não pela sua especificação e suas funções teóricas positivas ou normativas, mas pelos sentidos que ela assume para os atores - sentidos que, conforme antecipado no segundo contra-argumento, não são passíveis de dedução teórica. A nosso ver, quando perscrutada no plano do sentido, a autonomia é invocada por indivíduos inscritos em coletividades - grupos, associações, movimentos, comunidades - para significar a relação dessas coletividades com outros

\footnotetext{
${ }^{21}$ Se no texto referido Dahl afirma "let me propose that to be autonomous in a political sense is to be not under the control of another" (DAHL, 1982, p. 16), um quarto de século antes formulou: "grupo é [considerado] autônomo na medida em que suas políticas não são controladas por indivíduos externos a ele” (DAHL, 1989, p. 80).
} 
GURZA LAVALLE, A.; SZWAKO, J. Sociedade civil, Estado e autonomia: argumentos...

atores civis, políticos ou econômicos. A significação das relações com outrem não é definitiva e sequer necessariamente estável, antes, varia conforme o ator aludido, as questões ou conflitos em jogo e até a presença ou não de terceiras partes. A autonomia aceita, por conseguinte, não apenas diversos sentidos num mesmo momento em relação a diversos atores ou instituições, mas inclusive em relação ao mesmo ator. O denominador comum é a afirmação de uma distância ou não ingerência considerada desejável (desiderato) e referida a práticas e circunstâncias específicas. Como desiderato, a autonomia pode ser invocada para significar tanto aquilo que se assegura que existe no mundo quanto aquilo que se reclama que deveria existir legitimamente - em ambos os casos, o agir autônomo do indivíduo, ator ou coletividade. Sobretudo, a invocação não remete diretamente a um estado de coisas no mundo - quer um período histórico sem interações, quer um momento de soberania irrestrita, quer um ato de autodeterminação pura -, mas à autopercepção dos atores das suas relações com outrem em sistemas de interdependência que envolvem diversos atores. Nesses termos, a compreensão analítica da autonomia passa pela compreensão da representação nativa feita pelos atores a respeito das suas trocas, dívidas e dessimetrias com outros atores políticos e também civis.

Assim, desvendar os sentidos da autonomia implica examinar as diversas circunstâncias em que ela é invocada na prática dos atores, atentando para a atualização de significados específicos produzidos por tal invocação. Trilhando caminhos próprios, diversos esforços na literatura brasileira têm acionado a autonomia, dedicando-se a escrutinar seus sentidos na prática dos atores, bem como a criticar e a revisitar o modo pelo qual ela é, ou pode ser, apreendida por lentes analíticas menos prescritivas. A renovação conceitual comum a pesquisas mais recentes consiste em assentar o pressuposto de que autonomia não é - nem deve ser tomada como - sinônimo de não relação com o Estado e, mais amplamente, com o sistema político (TATAGIBA, 2008). Em parte dessas investigações, trata-se de escrutinar percepções nativas de autonomia e sua relação com recursos/atributos e com trajetórias/dinâmicas efetivas de participação (CAYRES, 2009). A preocupação de Cayres (2009) com os sentidos nativos de autonomia e o respectivo cuidado metodológico, que diferencia níveis individual e organizacional de análise, permitem-Ihe ensejar uma tipologia não da autonomia, mas sim das autonomias, no plural, tal como vividas e disputadas nos conselhos. Em outra vertente, Tatagiba (2010) ressalta as armadilhas, ambiguidades e mesmo aporias nas quais se veem enredados os movimentos diretamente orientados para as instituições políticas:

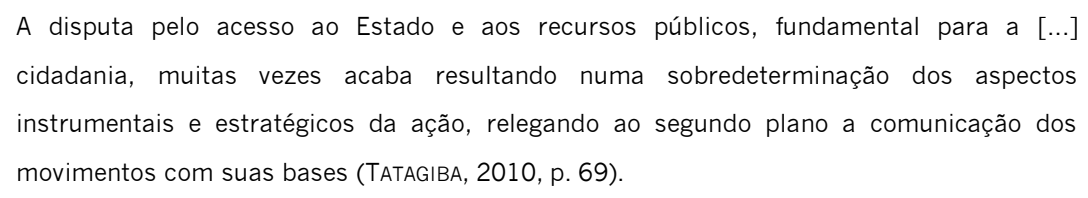

Essa análise encerra um duplo avanço no debate. Por um lado, seu pressuposto relacional de investigação em nada lembra aquela concepção herdada e hipostasiada de autonomia: os movimentos estão estrategicamente em meio a disputas partidárias e burocráticas, e não são essas interações que fatidicamente 'tiram' deles sua atuação 'autônoma'. Por outro lado, porém, em seus efeitos, tais interações pesam sobre os movimentos, que vivem sob a tensão inerente entre a reivindicação de sua ‘autonomia' e a eficácia de suas lutas e conquistas políticas (TATAGIBA, 2010). 
Em consonância com esses esforços, outros empreendimentos analíticos recentes vêm escrutinando as percepções dos atores nas várias formas de aproximação entre Estado e atores da sociedade civil, dentre as quais se destacam as chamadas 'parcerias' (LIMA NETO, 2013; REIS, 2013). Em sua análise das relações entre uma Superintendência Regional do Instituto Nacional de Colonização e Reforma Agrária (Incra) e movimentos de luta por terra (Movimento dos Trabalhadores Rurais Sem Terra, Federação dos Trabalhadores da Agricultura, Federação dos Trabalhadores na Agricultura Familiar), Penna (2013) observa como o padrão de interação entre esses atores estabeleceu um repertório de ações públicas sedimentado e sintetizado na figura nativa da "relação de parceria". Por meio dessa expressão, tanto burocratas como militantes expressam as táticas pelas quais o movimento influencia a Superintendência, seja na seleção de terras expropriáveis seja na de famílias a serem assentadas. E mais: mesmo sedimentada como condição para a distribuição de terras, a 'parceria' entre partes do Incra e os movimentos não extirpou modalidades mais conflitivas de ação pelos últimos, a exemplo, sobretudo, das ocupações na sede da Superintendência. Já em sua análise dos efeitos nos padrões de ação coletiva das relações entre movimentos e instituições participativas no Espírito Santo, Carlos (2012) mostra a significação de parte das interações com o poder público em termos de 'parceria'. Observando, desde os anos 1980, a trajetória das formas de aproximação entre a Federação das Associações de Moradores da Serra (Fams) e o respectivo executivo municipal - apenas um dos casos por ela analisados -, a autora destaca que a transformação no padrão de ação da Fams e nos seus objetivos corresponde tanto "à incorporação de novas atividades relevantes na vida associativa desta coletividade" quanto "a mudanças no Estado, à ampliação do acesso às agências governamentais e à implementação de instituições participativas de elaboração de políticas públicas" (CARLOS, 2012, p. 151).

Nos dois casos, vê-se como as mudanças tático-organizacionais dos atores civis caminham pari passu à interação com os respectivos poderes executivos, por sua vez, interpelados por saberes e dinâmicas advindas desses atores, sem que a ampliação e a intensificação das trocas entre ambos anulem ou - no jargão do debate - 'cooptem' os atores ou desvirtuem irremediavelmente suas táticas consagradas, inclusive as de índole disruptiva. São, então, essas lógicas, dinâmicas e dessimetrias que interessam à agenda do interacionismo socioestatal, e cuja caracterização vem ganhando densidade graças à pesquisa empírica que assume a interdependência como ponto de partida, e não como ponto de chegada da investigação.

\section{A guisa de conclusão: sentidos da autonomia e interdependência} entre Estado e sociedade civil

Para finalizar, antes de retomar pontualmente os contra-argumentos, de modo a explicitar suas implicações mais diretas para a pesquisa empírica, abordamos de modo breve dois casos que, embora extemporâneos e cronologicamente distantes, permitem elucidar os contra-argumentos de forma integrada. Com maior precisão, os dois casos permitem mostrar o rendimento heurístico dos contra. argumentos aqui aventados, isto é, de compreensões que assumem o caráter mutuamente constitutivo do Estado e da sociedade civil e privilegiam interpretações interacionistas e de cunho relacional. 0 
GURZA LAVALLE, A.; SZWAKO, J. Sociedade civil, Estado e autonomia: argumentos...

primeiro caso é elucidativo em relação aos sentidos da 'autonomia' e o segundo, em relação à codeterminação Estado-sociedade civil.

A análise de $\mathrm{E}$. Carlos oferece indícios sobre os diferentes registros nos quais a autonomia foi invocada durante o contexto da ditadura e da transição. Em sentido contrário de leituras autonomistas em que a invocação da autonomia por parte dos atores é interpretada como não relação com os executivos locais ou partidos, Carlos assevera que a invocação da autonomia - em falas como "a Fams e o movimento popular não têm donos, nem partido político" (CARLOS, 2012, p. 100) - pelas organizações populares por ela analisadas reivindicava (desiderato) que os partidos não se interpusessem entre elas e o Estado, ao mesmo tempo em que mantinham laços com ambos, atores partidários e estatais. Nas suas palavras,

a tentativa de delimitar os espaços de atuação e garantir o direito de organização popular fora das instituições políticas [implicou, ao longo dos anos 1980,] a recusa da mediação dos canais tradicionais na relação com o Estado e a busca de uma relação direta e sem intermediação entre o movimento e o Estado (CARLOS, 2012, p. 117).

A invocação da autonomia, todavia, não foi e nem é unívoca, e tampouco é categoria a significar apenas as práticas dos movimentos, pois a zona socioestatal onde eles se situam, vinculante das sociedades civil e política, engloba também outros atores. No caso da Fams - e plausivelmente em muitos outros -, essa zona englobava frações progressistas da Igreja Católica e correntes do Partido dos Trabalhadores que, por sua vez, tinham concepções próprias de autonomia a organizar a autopercepção de suas relações interdependentes, significando distanciamento em aspectos considerados críticos. Enquanto na visão de membros das Comunidades Eclesiais de Base "a aproximação entre o movimento popular e o ativismo partidário era indesejável" (CARLOS, 2012, p. 105), membros do diretório local petista denunciavam "a atitude paternalista, de 'protetor do rebanho', de alguns agentes pastorais" (CARLOS, 2012, p. 106). Presumivelmente, para os segundos a ascendência da igreja sobre a mobilização popular apresentava-se como empecilho a projetos mais radicais e o distanciamento, ou a autonomia, era considerado desejável; já para os primeiros, o dirigismo do partido sobre os atores populares é que devia ser conjurado. Plenos de tensão e ambiguidade, esses indícios sugerem tanto a riqueza empírica dos registros nativos em que a autonomia pode ser invocada e reivindicada, como a fineza analítica exigida para a compreensão dos sentidos das autonomias.

Voltando mais no tempo, mas agora pensando na interação entre atores sociais e estatais, a análise de A. Silva Jr. das estratégias públicas das mutuais do século XIX evidencia como - longe de ser uma característica própria das relações entre Estado e sociedade civil do período pós-Constituinte - o associativismo, nesse caso, mutualista, transformou-se em consonância e em relação com as instituições políticas. Não foram poucas as formas pelas quais essas associações de ajuda acessaram o Estado e seus recursos, do mesmo modo que não foi pouco o investimento estatal para estabilizar suas relações com as mutuais (SILVA JR., 2004, p. 296-ss.): a variedade encontrada nas formas de tipificação jurídica distinguindo entidades 'beneficentes' de 'montepios' e de 'sociedade de socorro mútuo'-; as nomeações oficiais de presidentes de entidade, bem como as subvenções diretas ou indiretas, via loterias ou com isenção fiscal, eram três dos modos pelos quais associações mutualistas e Estado se relacionaram. 
Como é de se imaginar, os padrões de interação socioestatal se alteram significativamente com a mudança na forma de governo:

as subvenções às entidades indicam relações diferentes entre Estado e mutuais nos períodos imperial e republicano, pois, no primeiro caso, as subvenções podem ser prodigalizadas às associações que o governante desejar, ao passo que, no segundo caso, estão limitadas pelos valores gerais do orçamento (SILVA JR., 2004, p. 316).

Essa variação se reflete também no âmbito de legislação no qual tais entidades eram situadas: na sociedade econômica, pela legislação do Império, e, na sociedade civil, ao menos pelas leis da República Velha (SILVA JR., 2004, p. 341). A versatilidade das mutuais era a um só tempo circunscrita e animada por essas mudanças no laço socioestatal, de modo que suas estratégias - ressoando um Offe eram "dependentes da definição (ou indefinição) do caráter público das entidades" (SILVA JR., 2004, p. 525). E, além disso, no alvorecer do século XX, a modernização e a complexificação da ecologia da sociedade civil novecentista pesaram institucionalmente, por meio do Decreto 1.637 de 1907. Tal decreto regulamentava a organização interna e financeira dos então nascentes sindicatos e, ao regulá. los, e por isso mesmo, dava os primeiros contornos institucionais de um domínio de agência clássico ${ }^{22}$, interferindo, porém, "na dinâmica interna das entidades existentes, quando estimula a criação de novas sociedades de socorros mútuos, e, mais precisamente, aquelas por categoria profissional" (SILVA JR., 2004, p. 304). Essa intervenção trouxe efeitos de curto e longo prazo no perfil do mutualismo ${ }^{23}$. Mais uma vez, é possível, com lentes relacionais e a partir de um caso oitocentista, apreender a codeterminação entre sociedade civil e Estado, bem como as dinâmicas, em maior ou menor medida estáveis, de relação entre um e outro.

A propósito do diagnóstico de conjunto de L. Avritzer (2012) sobre as mudanças nas relações entre sociedade civil e Estado no Brasil nas últimas décadas, que reatualiza teses caras à literatura de

\footnotetext{
22 Sobre a gênese, o perfil ideológico e as dinâmicas crescentes de complexificação e centralização do sindicalismo paulista nas três primeiras décadas do XX, veja-se Simão (1981, p. 156-ss.); sobre a delimitação de um domínio de agência propriamente sindical consagrado no e pelo Estado Novo, veja-se: "[a]s mudanças observadas na associação sindical revelam terem elas se projetado no sentido da complexidade e burocratização [...], heteronomia e centralização organizatórias. A intervenção do governo no sindicato não contrariou, mas acelerou aquelas mudanças [...]. Promoveu ela mesma uma transformação da mais relevante consequência: a passagem do sindicato marginal ao Estado para o sindicato integrado na própria instituição do Estado. Com isso, alteraram-se a estrutura e as funções das antigas ligas de resistência operárias. Mas se alteraram, também, a organização e as funções do Estado. E tais mudanças não representam ocorrências confinadas ao âmbito de uma ou outra instituição. Elas se modificam concomitante e reciprocamente no processo indicado pelos fatos analisados. Como resultado, observam-se a extensão e a interpenetração das estruturas e funções do sindicato e do Estado" (SıMÃo, 1981, p. 186-187) (grifos nossos).

${ }^{23}$ A citação é longa, mas vale a pena: "[tal decreto] interfere também porque, mesmo nas então criadas caixas adjuntas aos sindicatos, estipula a contabilidade em separado, demarcando a distinção entre os fundos destinados à proteção social e aqueles destinados à promoção de estratégias coletivas. A forma por meio da qual a lei faculta a criação de caixas de socorros mútuos explicita eventuais necessidades de justificar ideológica ou politicamente sua inexistência nos sindicatos a partir de então criados. Ao se comparar a fundação de sociedades de socorro mútuo entre 1897 e 1906 e entre 1908 e 1917 , verifica-se que o incentivo legal poderia ser considerado eficiente, ao se criarem 13 caixas profissionalmente diferenciadas no período mais recente, contra 9 do período anterior no Rio Grande do Sul. A diferença é pequena, e poderia ser atribuída ao processo mesmo de conformação de identidade profissional ao longo do tempo, mas o peso da norma se torna mais evidente quando se comparam os tempos médios de funcionamento nos dois períodos: enquanto as entidades criadas antes de 1907 funcionam por cerca de 19 anos e 4 meses, as criadas posteriormente funcionam por 9 anos, o que indicaria que, na falta do estímulo legal, as expectativas de manutenção de mutuais se pautariam exclusivamente pela avaliação da capacidade profissional de as sustentarem, expectativas tendencialmente mais realistas. Mesmo desviada a atenção do longo período de montagem da previdência estatal no Brasil, e de seus efeitos em sociedades de socorro mútuo, não é possível deixar de assinalar que, ainda recentemente, disposições legais e administrativas interferem nas relações de ambas" (SILVA JR., 2004, p. 204-305).
} 
GURZA LAVALLE, A.; SZWAKO, J. Sociedade civil, Estado e autonomia: argumentos...

sociedade civil e movimentos sociais no Brasil, este artigo desenvolveu quatro contra-argumentos igualmente balizados pela tese da mútua determinação entre Estado e sociedade civil, lançando mão dos avanços no debate e da produção de conhecimento no país.

Primeiro, olhamos para o século XIX e, acompanhando a literatura de ponta, mostramos lá uma agitação societal - antiescravagista ou mutualista ou religiosa -, à altura de latitudes 'modernas de nascimento' e, para nós, irreconciliável com um diagnóstico de modernidade e emergência tardias da sociedade civil, entre nós, apenas no final do terceiro quartel do século XX. Essa compreensão, que situa na década de 1970 a emergência da sociedade civil brasileira, a nosso ver, não estima a complexidade própria ao passado, reservando a ele falta de pluralidade e de densidade. Pelos motivos e evidências expostos, esse não é um ponto de partida adequado. Em vez de leituras anacrônicas, as análises dedicadas aos atores civis e às suas relações com o Estado se enriqueceriam se se valessem da riqueza heurística da noção de sociedade civil com a condição de respeitar as formas historicamente existentes de diferenciação entre Estado e sociedade. Sem esse respeito, a um só tempo teórico e empírico, a análise resta comprometida e, alinhada ao senso comum e à idealização do tempo presente, condena o passado àquilo que ele supostamente não foi e sequer pretendeu ser.

Em seguida, e em consonância com enfoques histórico-institucionalista e de raiz gramsciana, abordou-se a codeterminação entre Estado e sociedade civil e a implausibilidade de caracterizar os anos 1970 e 1980 como um período de 'autonomia plena'. Sustentamos a importância do pressuposto analítico da mútua constituição entre Estado e sociedade civil, o qual exige um tratamento relacional da autonomia. Nesses termos, a tarefa passa a ser esquadrinhar os padrões da interdependência entre atores sociais e estatais, a constituição e/ou as consequências desses padrões, bem como as mudanças na natureza dessa interdependência ao longo do tempo. No reverso dessa tarefa assume-se a crítica a posturas que positivam em vez de problematizar e decodificar usos práticos da 'autonomia', pois, para dizê-lo emprestando a formulação sintética de Dagnino, "sociedade civil e Estado são sempre mutuamente constitutivos" (DAGNINO, 2011, p. 124).

O terceiro contra-argumento se concentrou na crítica a uma acepção esvaziada de "interdependência", ante a qual se aventaram as possibilidades exploradas na literatura nacional, atentando para concepções relacionais de autonomia e para o desenvolvimento de categorias de médio alcance e suficientemente plásticas e sensíveis ao mundo empírico. Categorias como, por exemplo, projeto político e domínio de agência, assim como análises de interfaces socioestatais, suas condições e seus efeitos institucionais, marcam um avanço no debate por abrir caminhos para pesquisar a institucionalização dos atores da sociedade civil, suspendendo a preocupação quanto ao sinal que a ela deve ser atribuído. Em alguns casos, os atores não estatais atuam por dentro do Estado e dos partidos, através das instituições participativas ou, mesmo, a despeito delas; já em outros, não tão raros como de praxe se imagina, militantes tornados autoridades ou as próprias autoridades passam a promover uma espécie de ativismo institucional do Estado. São, pois, diversas as combinações e rotas de interdependência entre Estado e sociedade civil, do mesmo modo que são variadas as categorias analíticas mobilizadas para dar conta do cenário de intensificação e ampliação das trocas socioestatais. Por um lado, como argumentamos, tentativas de salvaguardar no plano teórico a autonomia dos atores 
civis levam a aporias como "interdependência sem dependência" - figura talvez afeita à autoimagem dos atores civis, mas pouco condizente com exigências explicativas. As ricas transformações sociopolíticas ocorridas nas últimas duas décadas demandam interpretações baseadas em categorias relacionais, de médio alcance e menos preocupadas com resguardar alguma essência virtuosa dos atores da sociedade civil.

Tal virtuosidade esteve, por bom tempo, ancorada na projeção estilizada dos reclamos de 'autonomia' dos atores sociais para o plano da teoria. Assim, tratamos as diferenças entre a autonomia como categoria teórica e a autonomia como categoria prática, bem como as perdas cognitivas derivadas da indistinção ou fusão entre ambos os registros. O debate nacional avançou e, diretamente informados pelas pesquisas empíricas recentes, mostramos o refinamento das pesquisas sobre movimentos sociais e sociedade civil relativamente às questões de autonomia, reconceituando tal categoria de modo a Ihe restaurar a capacidade analítica. Esses avanços são conclusivos em um ponto: é equivocado entender a autonomia - da sociedade civil ou dos movimentos sociais - como ausência de relação - com o Estado, nesse caso. Se tomada como não relação, a autonomia se torna um obstáculo epistemológico, quer dizer, obstáculo de pensamento contra o próprio pensamento (BACHELARD, 1972 [1934]). Assim, longe de ser ausência de interação com atores políticos, a autonomia como categoria nativa exige o escrutínio dos modos práticos de sua invocação nas, e por meio das, configurações concretas em que ela é mobilizada. A apreensão relacional dos movimentos e atores civis permite escrutinar os significados nativos atribuídos às relações por eles travadas com o Estado e o sistema político, iluminando a percepção da distância desejada/invocada ou suposta/afirmada, por parte desses atores, em relação a outros atores do Estado, do mercado ou da própria sociedade civil; percepção inscrita nos padrões de interação socioestatal e, a um só tempo, deles tributária e constitutiva.

Ainda não dispomos de diagnósticos de conjunto satisfatórios sobre as transformações ocorridas nas últimas décadas quanto aos padrões de interação entre Estado e sociedade civil, e os avanços do debate têm seguido de modo frutífero o caminho da especialização. Contudo, à luz desses contra-argumentos e das fontes teóricas e empíricas que os animam, os diagnósticos que por ventura vierem a se estabilizar terão que nos oferecer um diagnóstico de conjunto não "da autonomia à interdependência", mas 'da interdependência à interdependência'; isto é, uma compreensão das mudanças de certos padrões de codeterminação à emergência e à cristalização de novos padrões de mútua determinação entre Estado e sociedade civil.

\section{Referências Bibliográficas}

ABERS, R. N.; KECK, M. "Mobilizing the State: the erratic partner in Brazil's participatory water policy". Politics \& Society, vol. 37, n², p. 289.314, 2009.

ABERS, R.; KeCK, M. Practical authority: agency and institutional change in Brazilian water politics. Oxford University Press, 2013.

ABERS, R.; Von BULow, M. "Movimentos sociais na teoria e na prática: como estudar o ativismo através da fronteira entre Estado e sociedade?". Sociologias, vol. 13, n² 28, p. 52-84, 2011. 
Alonso, A. "Associativismo avant la lettre: as sociedades pela abolição da escravidão no Brasil oitocentista". Sociologias, vol. 28, p. 169-199, 2011.

AMENTA, E., et al. "Challengers and States: toward a political sociology of social movements". Sociological Views on Political Participation, vol. 10, p. 47.83, 2002.

AmENTA, E., et al. "Age for leisure? Political mediation and the impact of the pension movement on US old-age policy". American Sociological Review, n 70, p. 516-38, 2005.

AmENTA, E., et al. "The political consequences of social movements". Annual Review of Sociology, vol. 36, p. 287-307, 2010.

AssIES, W. To get out of the mud: neighborhood associativism in Recife, 1964-1988. Amsterdam: Cedla, 1991.

AvritZer, L. A moralidade da democracia. São Paulo: Perspectiva/UFMG, 1996.

“Um desenho institucional para o novo associativismo". Lua Nova, São Paulo, vol. 1, n 39, p. 149.174, 1997.

Participatory institutions in democratic Brazil. Washington: Johns Hopkins University Press, 2009.

"Sociedade civil e Estado no Brasil: da autonomia à interdependência política". Opinião Pública, vol. 18, n², p. 383-398, 2012.

Avritzer, L.; Navarro, Z. (orgs.). A inovação democrática no Brasil. São Paulo: Cortez, 2003.

BACHeLARD, G. La formación del espírito científico. Buenos Aires: Siglo XXI Editores, [1934], 1972.

BARRos, R. S. M. Vida religiosa. In: História geral da civilização brasileira. Rio de Janeiro: Bertrand Brasil, 2004.

Bendix, R. Construção nacional e cidadania. São Paulo: Edusp, [1964], 1996.

BoschI, R. A arte da associação: política de base e democracia no Brasil. São Paulo: Vértice, 1987.

Bourdieu, P. A economia das trocas linguísticas: o que falar quer dizer. São Paulo: Edusp, 1998.

Brant, V. C., et al. (orgs.). São Paulo: o povo em movimento. São Paulo: Vozes, 1982.

BuRgos, R. "Sem glória, mas com certa pena: mais uma vez sobre o conceito de sociedade civil no Brasil". Texto apresentado no IV Seminário Nacional "Movimentos sociais e participação no Brasil: diálogos transversais", Florianópolis, 10 de abril de 2014.

CARdoso, R. Movimentos sociais urbanos: balanço crítico. In: SoRJ, B.; ALmeIDA, M. H. T. (orgs.). Sociedade política no Brasil pós-64. São Paulo: Brasiliense, 1983.

CARLOS, E. "Movimentos sociais e instituições participativas: efeitos organizacionais, relacionais e discursivos". Doutorado em Ciência Política, Universidade de São Paulo, 2012.

Carvalho, J. M. Os bestializados. O Rio de Janeiro e a república que não foi. São Paulo: Companhia das Letras, 1996.

CAYRES, D. "Sociedade civil e Estado: a autonomia revisitada". Dissertação de Mestrado em Sociologia Política, Universidade Federal de Santa Catarina, 2009.

ChaUI, M. Prefácio. In: SADER, E. Quando novos personagens entraram em cena: experiências, falas e lutas dos trabalhadores da Grande São Paulo (1970-80). Rio de Janeiro: Paz e Terra, 1988.

CLEMENS, E. "Organizational repertoires and institutional change: women's groups and the transformation of U.S. politics, 1890-1920". American Journal of Sociology, vol. 98, 1993.

COLlier, R.; Collier, D. Shaping the political arena: critical junctures, the labor movement, and regime dynamics in Latin America. Princeton University Press, 1991. 
Cornwall, A.; Coelho, V. S. The politics of citizen participation in new democratic arenas. In: Spaces for change? Londres: Zed Books, p. 1·29, 2007.

Costa, S. "Esfera pública, redescoberta da sociedade civil e movimentos sociais no Brasil". Novos Estudos Cebrap, vol. 38, p. 38-52, 1994.

"Categoria analítica ou passe-partout político-normativo: notas bibliográficas sobre o conceito de sociedade civil". Revista Brasileira de Informação Bibliográfica, nº 43, p. 3-25, 1997.

CROWLEY, J. E.; SKOCPOL, T. "The rush to organize: explaining associational formation in the United States, 1860s-1920s". American Journal of Political Science, vol. 45, n 4, p. 813-129, 2001.

Dagnino, E. Civil society in Latin America. In: Edwards, M. (org.). The Oxford handbook of civil society. Oxford: Oxford University Press, 2011.

Dagnino, E.; Olvera, A.; PANFICHI, A. Para uma outra leitura da disputa pela construção democrática na América Latina. In: Dagnino, E.; Olvera, A.; Panfichi, A. (orgs.). A disputa pela construção democrática na América Latina. São Paulo: Paz e Terra; Campinas: Editora da Unicamp, 2006.

DAHL, R. Dilemmas of pluralist democracy. New Haven: Yale Universtity Press, 1982.

Um prefácio à teoria democrática. Rio de Janeiro: Zahar, [1956], 1989.

DINIZ, E.; BoschI, R. A consolidação democrática no Brasil: atores políticos, processos sociais e intermediação de interesses. Rio de Janeiro: luperj/Vértice, 1989.

Doımo, A. M. Movimento social urbano, Igreja e participação popular. Petrópolis: Vozes, 1984.

A vez e a voz do popular: movimentos sociais e participação política no Brasil pós-70. Rio de Janeiro: Relume Dumará/Anpocs, 1995

DOWBOR, M. "A arte da institucionalização: estratégias de mobilização dos sanitaristas (1974-2006)". Doutorado em Ciência Política, Universidade de São Paulo, 2012.

DWORKIN, G. The theory and practice of autonomy. New York: Cambridge University Press, 1988.

ELIAS, N. O processo civilizador. formação do Estado e civilização, vol. 2. Rio de Janeiro: Jorge Zahar Editor, 1993.

A sociedade dos indivíduos. Rio de Janeiro: Jorge Zahar, 1994.

ESCOREL, S. Reviravolta na saúde: origem e articulação do movimento sanitário. Rio de Janeiro: Fiocruz, 1998.

Faustino, E. "O catolicismo em São Paulo no Segundo Império e o ‘Dilema da Modernidade'”. Mestrado em História Social, Universidade de São Paulo, 1991.

“O renitente catolicismo popular". Doutorado em História Social, Universidade de São Paulo, 1996.

GIUMBELLI, E. "Religião e (des)ordem social: Contestado, Juazeiro e Canudos nos estudos sociológicos sobre movimentos religiosos". Dados, Rio de Janeiro, vol. 40, n² 2, p. 251-282, 1997.

GoHn, M. G. Teorias dos movimentos sociais: paradigmas clássicos e contemporâneos. São Paulo: Loyola, 1997.

Gurza lavalle, A. Vida pública e identidade nacional: leituras brasileiras. São Paulo: Globo, 2004.

Gurza lavalle, A.; HoutZager, P.; CAstello, G. "Democracia, pluralização da representação e sociedade civil". Lua Nova. São Paulo, nº 67, 49.103, 2006a.

Gurza lavalle, A.; Houtzager, P.; CAstello, G. "Representação política e organizações civis: novas instâncias de mediação e os desafios da legitimidade". Revista Brasileira de Ciências Sociais, vol. 21, n 60, 2006b. 
GURZA LAVALLE, A.; SZWAKO, J. Sociedade civil, Estado e autonomia: argumentos...

Gurza lavalle, A.; Houtzager, P.; Castello, G. A construção política das sociedades civis. In: Gurza Lavalle, A. (org.). 0 horizonte da política: questões emergentes e agendas de pesquisa. São Paulo: Editora da Unesp, p. 185-259, 2012.

Gurza Lavalle, A.; IsUnZA, E. Precisiones conceptuales para el debate contemporáneo sobre la innovación democrática. In: IsUnZA, E.; GuRZa LAVALle, A. La innovación democrática en América Latina. Tramas y nudos de la representación, la participación y el control social. México: Ciesas-Universidad Veracruzana, p. 17·82, 2010.

HABERMAS, J. The theory of communicative action //. Lifeworld and system: a critique of funcionalist reason. Boston: Bacon Press, [1982], 1987.

Historia y crítica de la opinión pública. La transformación estructural de la vida pública. Ciudad de México: Gustavo Gili, [1962], 1994.

HaLL, P. "Policy paradigms, social learning, and the state: the case of economic policymaking in Britain". Comparative Politics, vol. 25, n³, p. 275.296, 1993.

HoCHSTETLER, K.; KeCK, M. Greening Brazil: environmental activism in state and society. Durham (NC): Duke University Press, 2007.

HoutZager, P. Os últimos cidadãos: conflito e modernização no Brasil rural (1964-1995). São Paulo: Globo, 2004.

IfFLy, C. Transformar a metrópole: Igreja Católica, territórios e mobilizações sociais em São Paulo, 1970-2000. São Paulo: Editora da Unesp, 2010.

IMmERGUT, E. Health politics: interests and institutions in Western Europe. Cambridge: Cambridge University Press, 1992.

ISUNZA, E. Para analizar los procesos de democratización: interfaces socioestatales, proyectos políticos y rendición de cuentas. In: ISUNZA, E.; OLVERA, A. J. (coords.). Democratización, rendición de cuentas y sociedad civil: participación ciudadana y control social. Colección "Conocer para decidir", Cámara de Diputados, LIX Legislatura. México: Ciesas/Universidad Veracruzana/Miguel Ángel Porrúa, pp. 265-291, 2006.

ISUnZA, E.; HeviA, F. "Relaciones sociedad civil-Estado en México. Un ensayo de interpretación". Cuadernos para la Democratización, $n^{\circ}$ 4, Programa Interinstitucional de Investigación-Acción sobre Democracia, Sociedad Civil y Derechos Humanos, México/Xalapa: Ciesas/Universidad Veracruzana, 2006.

Jesus, R. P. "A Revolta do Vintém e a crise na Monarquia". História Social, Campinas, vol. 12, p. 73-89, 2006.

. "Associativismo no Brasil do século XIX: repertório crítico dos registros de sociedades no Conselho de Estado (1860-1889)". Locus - Revista de História. Juiz de Fora, vol. 13, n 1, p. 144-170, 2007.

LIMA NETO, F. C. "Relação com o Estado na visão das ONGs: uma sociologia das percepções". Texto para discussão (Ipea, Brasília), vol. 1820, p. 7-32, 2013.

LÜCHMANN, L. H. “Associações, participação e representação: combinações e tensões”. Lua Nova, n 84, 2011.

Machado da Silva, L.; RibeiRo, A. C. "Paradigma e movimento social: por onde andam nossas ideias". Ciências Sociais Hoje, São Paulo: Vértice/Anpocs, n² 2, p. 318-336, 1985.

Machado, M. H. O plano e o pânico: os movimentos sociais na década da abolição. 2a ed. São Paulo: Edusp, 2010.

MAHONEY, J.; RUESCHEMEYER, D. Comparative historical analysis: achievements and agendas. In: Comparative historical analysis in the social sciences. NY: Cambridge University Press, 2003.

OLIVEIRA, F. Privatização do público, destituição da fala e anulação da política: o totalitarismo neoliberal. In: Os sentidos da democracia: políticas do dissenso e hegemonia global. Petrópolis/Rio de Janeiro: Vozes, 2000.

Olvera, A. Sociedad civil, espacios públicos y democratización en América Latina. Ciudad de México: Fondo de Cultura Económica, 2004. 
PAOLI, M. C. Movimentos sociais no Brasil: em busca de um estatuto político. In: Movimentos sociais e democracia no Brasil. São Paulo: Marco Zero, 1995.

PenNA, C. "Movimentos sociais e mudanças institucionais: o impacto dos movimentos de luta pela reforma agrária nas práticas do Instituto Nacional de Colonização e Reforma Agrária". Texto apresentado no $37^{\circ}$ Encontro da Associação Nacional de Pós-Graduação em Ciências Sociais, Águas de Lindoia, 2013.

PIRES, R. (org.). A efetividade das instituições participativas no Brasil: perspectivas, abordagens e estratégias de avaliação. Brasília: Ipea, 2011.

REIS, E. R. (org.). ONGs: novos vínculos entre a sociedade e o Estado. Rio de Janeiro: 7Letras, 2013.

Rizek, C.; PAolı, M. C. Depois do desmanche. In: A era da indeterminação. São Paulo: Boitempo, p. 7·14, 2007.

ROLlemBerg, D.; QuADRAT, S. (orgs.). A construção social dos regimes autoritários. Legitimidade, consenso e consentimento no século XX. Brasil e América Latina. Rio de Janeiro: Civilização Brasileira, 2010.

Romão, W. "O eclipse da 'sociedade política' nos estudos sobre o orçamento participativo". Revista Brasileira de Informação Bibliográfica em Ciências Sociais, vol. 70, p. 121-144, 2010.

2011.

"Conselheiros do Orçamento Participativo nas franjas da sociedade política". Lua Nova, n 84, p. 219.244,

SADER, E. Quando novos personagens entraram em cena: experiências, falas e lutas dos trabalhadores da Grande São Paulo (1970-80). Rio de Janeiro: Paz e Terra, 1988.

SCherer-WarRen, I. "Associativismo civil em Florianópolis: evolução e tendências". Revista de Ciências Humanas, Florianópolis, vol. 26, p. 115·134, 1999.

SerafiM, L. "Participação no governo Lula: as pautas da reforma urbana no Ministério das Cidades (2003.2010)". Doutorado em Ciências Sociais. Unicamp, 2013.

SILVA, M. K. "Sociedade civil e construção democrática: do maniqueísmo essencialista à abordagem relacional". Sociologias (UFRGS), vol. 8, p. 156-179, 2006.

SILVA JR., A. L. "As sociedades de socorros mútuos: estratégias privadas e públicas (estudo centrado no Rio Grande do Sul, Brasil, 1854-1940)". Doutorado em História, Pontifícia Universidade Católica do Rio Grande do Sul, 2004.

SILVA, M.; OliveIRA, G. "A face oculta(da) dos movimentos sociais: trânsito institucional e intersecção Estado-Movimento. Uma análise do movimento de Economia Solidária no Rio Grande do Sul”. Sociologias (UFRGS), vol. 13, p. 86.124, 2011.

SımÃo, A. Sindicato e Estado: suas relações na formação do proletariado de São Paulo. São Paulo: Ática, 1981.

SkocPoL, T. Protecting soldiers and mothers: the political origins of social policy in the United States. Cambridge, MA: Harvard University Press, 1992.

SouzA, L. A. M. "Afinal, o que é 'vontade política'? Uma perspectiva a partir da comparação entre as variações dos resultados de experiências de Orçamento Participativo". Texto apresentado no $37^{\circ}$ Encontro da Associação Nacional de Pós-Graduação em Ciências Sociais. Águas de Lindoia, 2013.

Steil, C.; HerRera, S. "Catolicismo e ciências sociais no Brasil: mudanças de foco e perspectiva num objeto de estudo". Sociologias [online], $\mathrm{n}^{\circ} 23$, p. 354-393, 2010.

SzWAKo, J. "Os sentidos da democracia: crítica, aposta e perplexidade na produção do Cenedic". Lua Nova. São Paulo, vol. $1, \mathrm{n}^{\circ} 78$, p. $251 \cdot 303,2009$.

"Incorporação e reprodução: ou como observar os efeitos institucionais da ação coletiva". Texto apresentado no $31^{\circ}$ Encontro da Latin American Studies Association, Washington DC, USA, 2013. 
TATAGIBA, L. "Movimentos sociais e sistema político: um diálogo (preliminar) com a literatura". $6^{\circ}$ Encontro da ABCP. Área Temática: Teoria política. Campinas, 2008.

"Desafios da relação entre movimentos sociais e instituições políticas: o caso do movimento de moradia da cidade de São Paulo - primeiras reflexões". Colombia Internacional, n 71, p. 63-83, 2010.

TeIXeIRA, A. C.; TAtAgIBA, L. Movimentos sociais e sistema político: os desafios da participação. São Paulo: Instituto Pólis/PUC.SP, 2005.

TILLY, C. Coerção, capital e Estados europeus. São Paulo: Edusp, 1996.

VERA, E. "El reto de la confluencia. Las interfaces socioestatales en el contexto de la transición política mexicana (dos casos para la reflexión)". In: DAGNINo, E.; OLVERA, A. J.; PANFICHI, A. La disputa por la construcción de la democracia en América Latina. Ciesas/Universidad Veracruzana/Fondo de Cultura Económica, México, p. 275-329, 2006.

Vera, E.; HeVIA, F. "Relaciones sociedad civil-Estado en México: un ensayo de interpretación". Cuadernos para la Democratización, n 4. Xalapa: Ciesas, 2006.

VISCARDI, C. "Estratégias populares de sobrevivência: o mutualismo no Rio de Janeiro republicano". Revista Brasileira de História, vol. 29, n 58, p. 291-315, 2009.

Wernet, A. A igreja paulista no século XIX. A reforma de D. Antônio Joaquim de Melo (1851-1861). São Paulo: Ática, 1987.

Adrian Gurza Lavalle - gurzalavalleadrian@gmail.com

José Szwako · zeszwako@hotmail.com

Submetido à publicação em novembro de 2013.

Versão final aprovada em dezembro de 2014. 